WSRC-TR-94-0287

Keywords: Nitrate, Nitrite, Destruction, Caustic, Solution, Nitrogen, Ammonia, Cathode, Anode

Retention Time: permanent

\title{
Summary Technical Report on the Electrochemical Treatment of Alkaline Nuclear Wastes (U)
}

July 30, 1994

Westinghouse Savannah River Company

P.O. Box 616

Aiken, SC 29802

Prepared for the Department of Energy Office of Technology Development, Office of Environmental Management under Contract DE-AC09-8\$SR18035 


\section{DISCLAIMER}

This report was prepared as an account of work sponsored by an agency of the United States Government. Neither the United States Government nor any agency thereof, nor any of their employees, makes any warranty, express or implied, or assumes any legal liability or responsibility for the accuracy, completeness, or usefulness of any information, apparatus, product, or process disclosed, or represents that its use would not infringe privately owned rights. Reference herein to any specific commercial product, process, or service by trade name, trademark, manufacturer, or otherwise does not necessarily constitute or imply its endorsement, recommendation, or favoring by the United States Government or any agency thereof. The views and opinions of authors expressed herein do not necessarily state or reflect those of the United States Government or any agency thereof.

This report has been reproduced directly from the best available copy.

Available to DOE and DOE contractors from the Office of Scientific and Technical Information, P.O. Box 62, Oak Ridge, TN 37831; prices available from (615) 576-8401.

Available to the public from the National Technical Information Service, U.S. Department of Commerce, 5285 Port Royal Road, Springfield, VA 22161. 


\section{DISCLAIMER}

Portions of this document may be illegible in electronic image products. Images are produced from the best available original document. 
WSRC-TR-94-0287

\title{
Summary Technical Report on the Electrochemical Treatment of Alkaline Nuclear Wastes (U)
}

\author{
by \\ D. T. Hobbs \\ DITS3 $8 / 15 / 94$
}

July 30, 1994

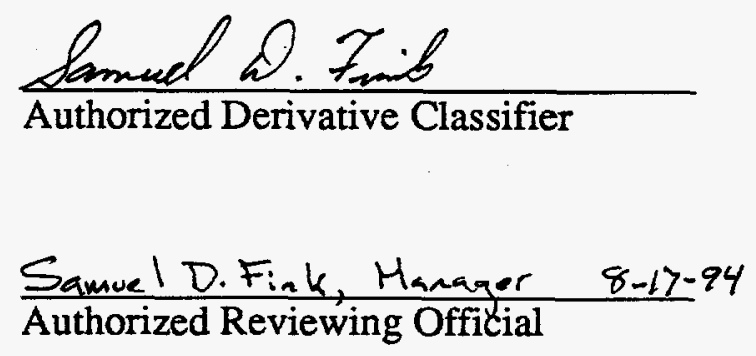

Savannah River Technology Center Westinghouse Savannah River Company Aiken, SC 29802

Prepared for the Department of Energy Office of Technology Development, Office of Environmental Management under Contract DE-AC09-88SR18035 


\section{SUMMARY}

This report summarizes the laboratory studies investigating the electrolytic treatment of alkaline solutions carried out under the direction of the Savannah River Technology Center from 1985-1992. Electrolytic treatment has been demonstrated at the laboratory scale to be feasible for the destruction of nitrate and nitrite and the removal of radioactive species such as ${ }^{99} \mathrm{Tc}$ and ${ }^{106} \mathrm{Ru}$ from Savannah River Site (SRS) decontaminated salt solution and other alkaline wastes. The reaction rate and current efficiency for the removal of these species are dependent on cell configuration, electrode material, nature of electrode surface, waste composition, current density, and temperature.

Nitrogen, ammonia, and nitrous oxide have been identified as the nitrogen-containing reaction products from the electrochemical reduction of nitrate and nitrite under alkaline conditions. The reaction mechanism for the reduction is very complex. Voltammetric studies indicated that the electrode reactions involve surface phenomena and are not necessarily mass transfer controlled. In an undivided cell, results suggest an electrocatalytic role for oxygen via the generation of the superoxide anion.

In general, more efficient reduction of nitrite and nitrate occurs at cathode materials with higher overpotentials for hydrogen evolution. Nitrate and nitrite destruction has also been demonstrated in engineering-scale flow reactors. In flow reactors, the nitrate/nitrite destruction efficiency is improved with an increase in the current density, temperature, and when the cell is operated in a divided cell configuration. Nafion ${ }^{\circledR}$ cation exchange membranes have exhibited good stability and consistent performance as separators in the divided-cell tests. The membranes were also shown to be unaffected by radiation at doses approximating four years of cell operation in treating decontaminated salt solution.

Tests indicate that the CoIII(cyclam) complex is an effective catalyst for the reduction of nitrate and nitrite in strong base, approximately to the same extent as in neutral or nonaqueous solutions. Nearly complete reduction of nitrate and nitrite to mixtures of hydroxylamine and ammonia takes place with reasonable current efficiencies at a variety of electrode materials.

\section{INTRODUCTION}

Production of nuclear materials within the Department of Energy complex has produced large volumes of high-level waste containing hazardous species such as nitrate, nitrite, chromium, and mercury. Processes being developed for the permanent disposal of these wastes are aimed at separating the bulk of the radioactivity, primarily ${ }^{137} \mathrm{Cs}$ and ${ }^{90} \mathrm{Sr}$, into a small volume for incorporation into a vitrified wasteform, with the remainder being incorporated into a low-level wasteform. Performance assessments of the low-level wasteforms indicate that major contributors to environmental release and personnel exposure risks include nitrate, nitrite, ${ }^{99} \mathrm{Tc}$ and ${ }^{106} \mathrm{Ru}$. The presence of organic compounds in alkaline wastes also presents concerns during interim storage of the waste in underground tanks and in the development of processes for separating the radioactive and non-radioactive components of the waste. For example, radiolytic decomposition of the organic compounds produces flammable gases. Also, the organic compounds may react with oxidizing agents in the waste releasing large quantities of energy. Complexants present in the waste such as ethylenediaminetetraacetate (EDTA) can bind radionuclides such as ${ }^{90} \mathrm{Sr}$ so that the required separation factors cannot be achieved. The destruction of the organic compounds would reduce the possible safety hazards associated with the storage of the waste in the underground storage tanks and allow development of efficient separation processes for the treatment of radioactive wastes. 
Electrochemical treatment is one possible technology for the destruction of nitrate, nitrite and organic compounds as well as the removal of radionuclides and hazardous metals from the waste solutions. In an electrochemical cell, nitrate and nitrite can be reduced to nitrogen-containing gases: nitrous oxide, nitrogen and ammonia. Half-cell reactions are shown below (1-4).

$$
\begin{array}{lll}
\mathrm{NO}_{3}^{-}+\mathrm{H}_{2} \mathrm{O}+2 \mathrm{e}^{-} & = & \mathrm{NO}_{2}^{-}+2 \mathrm{OH}^{-} \\
2 \mathrm{NO}_{2}^{-}+3 \mathrm{H}_{2} \mathrm{O}+4 \mathrm{e}^{-}= & \mathrm{N}_{2} \mathrm{O}+6 \mathrm{OH}^{-} \\
2 \mathrm{NO}_{2}^{-}+4 \mathrm{H}_{2} \mathrm{O}+6 \mathrm{e}^{-}= & \mathrm{N}_{2}+8 \mathrm{OH}^{-} \\
\mathrm{NO}_{2}^{-}+5 \mathrm{H}_{2} \mathrm{O}+6 \mathrm{e}^{-}= & \mathrm{NH}_{3}+2 \mathrm{OH}^{-}
\end{array}
$$

These gases have very low solubility in the alkaline salt solution and are released into the vapor phase, and thus separated from the solution phase. In an undivided cell, the corresponding anode reaction is the oxidation of hydroxide to oxygen and water. The net electrochemical reduction of nitrate or nitrite would then produce one equivalent of hydroxide per nitrate or nitrite reduced. Note that there are no additional chemicals added to the waste as a result of the electrochemical treatment.

$$
4 \mathrm{OH}^{-}=\mathrm{O}_{2}+2 \mathrm{H}_{2} \mathrm{O}+4 \mathrm{e}^{-}
$$

In addition to nitrate and nitrite, metal ions can be reduced producing solid phases or deposits on the electrodes, which can be separated from the solution phase. Possible examples of metal ions known to be in high-level waste that would be reduced based on standard electrochemical potentials include pertechnetate, ruthenate, chromate, and mercuric ion. Half-cell reactions for the reduction of these species are shown below (6-9).

$$
\begin{array}{ll}
\mathrm{TcO}_{4}^{--}+2 \mathrm{H}_{2} \mathrm{O}+3 \mathrm{e}^{-} & =\mathrm{TcO}_{2}+4 \mathrm{OH}^{-} \\
\mathrm{CrO}_{4}^{2-}+4 \mathrm{H}_{2} \mathrm{O}+3 \mathrm{e}^{-} & =\mathrm{Cr}(\mathrm{OH})_{3}+5 \mathrm{OH}^{-} \\
\mathrm{RuO}_{4}^{2-}+2 \mathrm{H}_{2} \mathrm{O}+2 \mathrm{e}^{-} & =\mathrm{RuO}_{2}+4 \mathrm{OH}^{-} \\
\mathrm{Hg}^{2+}+2 \mathrm{e}^{-} & =\mathrm{Hg}
\end{array}
$$

Oxidation of chemical species is also possible. For example, organic compounds can be electrochemically oxidized to produce carbon dioxide and water. The conditions necessary to affect the oxidation depend on the specific type(s) of organic compounds present. An example of an organic oxidation reaction is shown below for the ethylenediaminetetraacetate anion.

$$
\mathrm{C}_{10} \mathrm{H}_{12} \mathrm{~N}_{2} \mathrm{O}_{8}^{4-}+36 \mathrm{OH}^{-}=10 \mathrm{CO}_{2}+\mathrm{N}_{2}+24 \mathrm{H}_{2} \mathrm{O}+40 \mathrm{e}^{-}
$$

This report summarizes the results of experimental work carried out for the evaluation and development of the electrolytic technology for the treatment alkaline nuclear wastes. The major focus of the work has been to electrolytically destroy nitrate and nitrite in the alkaline salt solution that will be produced in the In-Tank Precipitation (ITP) process at the SRS and disposed of in a cement wasteform in the Saltstone facility. The application of this technology to other waste streams is also summarized.

During this work, an electrochemical separation process was also evaluated. Instead of reducing nitrate to a mixture of nitrogen, ammonia, and nitrous oxide gases, this process separates cationic and anionic components of the waste into two different product streams by migrating the charged species across ion-selective membranes under an externally applied potential. The results of the evaluation of the electrochemical separation process will be reported in a separate document. 


\section{EXPERIMENTAL}

Reagent Chemicals and Solutions

All salt solutions were prepared using Certified ACS Reagent Grade chemicals and deionized water. After combining all of the salts, the solutions were mixed for several hours, and then filtered to remove any undissolved solids. Solutions were stored in tightly capped polyethylene containers.

The majority of tests were carried out with a synthetic alkaline salt solution referred to as SRS Decontaminated Salt Solution. The composition of this solution is provided in Table I. The range of concentrations for each species spans the range that was tested over the course of the experimental studies. The composition of the other waste simulants are provided in the appropriate sections of the report.

Isotopically enriched $\mathrm{Na}^{15} \mathrm{NO}_{3}, \mathrm{NaOD}$, and $\mathrm{D}_{2} \mathrm{O}$ were obtained from Cambridge Isotope Laboratories. The [trans- $\mathrm{Cl}_{2} \mathrm{Co} I I I$ (cyclam) $] \mathrm{Cl}$ complex, where cyclam is $1,4,8,11$ tetraazacyclotetradecane (Aldrich), was prepared by literature procedures[1]. Ferrozine, 3-(2-pyridyl)-5,6-diphenyl-1,2,4-triazine-4,4'-disulfonic acid, was obtained from Fluka.

Table I. Composition of SRS Decontaminated Salt Solution

\begin{tabular}{lc} 
Species & Concentration $(\mathrm{M})$ \\
\hline $\mathrm{NO}_{3}{ }^{-}$ & $1.3-2.9$ \\
$\mathrm{NO}_{2}{ }^{-}$ & $0.52-0.71$ \\
$\mathrm{OH}^{-}$ & $1.3-2.0$ \\
$\mathrm{CO}_{3}^{2-}$ & $016-0.23$ \\
$\mathrm{Al}(\mathrm{OH})_{4}{ }^{-}$ & $0.32-0.38$ \\
$\mathrm{SO}_{4}^{2-}$ & $0.09-0.17$ \\
$\mathrm{~F}^{-}$ & $0-0.018$ \\
$\mathrm{Cl}^{-}$ & $0-0.026$ \\
$\mathrm{PO}_{4}{ }^{3-}$ & $0-0.010$ \\
$\mathrm{CrO}_{4}{ }^{2-}$ & $0-0.0040$ \\
$\mathrm{SiO}_{3}{ }^{2-}$ & $0-0.0046$ \\
$\mathrm{MoO}_{4}{ }^{2-}$ & $0-0.00051$ \\
$\mathrm{C}_{2} \mathrm{O}_{4}^{2-}$ & $0-0.0096$ \\
$\left.\mathrm{~B}^{2-} \mathrm{C}_{6} \mathrm{H}_{5}\right)_{4}^{-}$ & $0-0.0018$ \\
$\mathrm{Na}^{+}$ & $5.5-5.9$ \\
$\mathrm{Hg}^{2+}$ & $0-1.2 \times 10^{-7}$ \\
$\mathrm{Ru}^{2+}$ & $0-4.5 \times 10^{-5}$
\end{tabular}


Analytical Methods

Nitrate and nitrite concentrations were determined colorimetrically in the initial work reported by the International Hydronics Corporation. In all other testing, nitrate and nitrite concentrations, as well as that for other anions such as sulfate and phosphate, were determined by ion chromatography. Ammonia was determined by Kjeldahll titration, and hydroxylamine was determined by the ferrozine colorimetric procedure of Dias et al.[2]. Free hydroxide, total alkalinity, aluminate, and carbonate were determined using the analytical method developed by Bauman [3]. Sodium concentrations were determined by either atomic absorption spectroscopy or inductively-coupled plasma emission spectroscopy. Ruthenium-106 concentrations were determined by gamma counting and technetium-99 levels by beta-scintillation methods.

Samples of evolved gases were obtained and analyzed by either gas chromatography (GC) or mass spectrometry. Gas chromatographic analyses were performed on either a Perkin-Elmer 8500 or Varian 3400 gas chromatograph using a thermal conductivity detector. Nitrogen and ammonia were separated and quantified on a Chromasorb 103 column modified with $10 \%$ Versamide $900 / 8 \% \mathrm{KOH}$. Hydrogen, oxygen and nitrogen were separated and quantified on a molecular sieve $5 \mathrm{~A}$ column. The volumetric percentages of gases present in off-gas samples was determined by using a certified standard gas mix (Scott Specialty Gases) as an external standard for calibration of the GC. Mass spectrometric analyses were carried out by direct injection of gas samples into the EI ionization chamber of a VG instruments ZAB-EQ mass spectrometer. .

\section{Electrochemical Cells}

A variety of different electrochemical cells were utilized over the course of the testing. A reference name and descriptive features of each type of cell are given below:

Name

IHC-1

IHC-2

SRTC-1

SRTC-2

SRTC-3

Glass-1

Glass-2

Microflow

MP

FM01

\section{Description}

single rectangular acrylic cell $(20.0 \mathrm{~cm} \times 6.35 \mathrm{~cm} \times 30.5 \mathrm{~cm})$ seven cell reactor constructed of polypropylene $(30.5 \mathrm{~cm} \times 35.6$ $\mathrm{cm} \times 30.5 \mathrm{~cm}$ )

single rectangular HDPE cell $(20.2 \mathrm{~cm} \times 5.24 \mathrm{~cm} \times 22.7 \mathrm{~cm})$ single rectangular HDPE cell $(20.0 \mathrm{~cm} \times 6.35 \mathrm{~cm} \times 30.5 \mathrm{~cm})$ $500 \mathrm{~mL}$ round bottom flask equipped with two rectangular electrodes

H-Type Cell (Catalog \#C-100 cell available from the Electrosynthesis Company (Buffalo, NY)

H-Type Cell (Catalog \#C-600 membrane cell available from the Electrosynthesis Company (Buffalo, NY)

parallel-plate flow cell manufactured by ElectroCell AB (Sweden), electrode working area $0.001 \mathrm{~m}^{2}$

parallel-plate flow cell manufactured by ElectroCell AB (Sweden), electrode working area $0.01 \mathrm{~m}^{2}$

parallel-plate flow cell manufactured by ICI, Ltd. (Great Britain), electrode working area $0.0064 \mathrm{~m}^{2}$ 
Electrodes and Materials

A variety of electrode materials were utilized over the course of the testing. Specific details for the source and size for each electrode material are provided in the individual reports and publications. Prior to use each electrode was cleaned by washing with detergent and rinsing with copius quantities of deionized, distilled water. For voltammetric studies, the electrodes were generally polished with $0.3 \mathrm{~mm}$ lapping compound just prior to cleaning.

The iron-phthalocyanine electrodes were prepared following the procedure of Wohrle et al. [4]. Iron foil ( $2 \mathrm{~mm}$ thick) was pretreated by polishing first with sand paper and then lapping compound (25-0.3 mm), etching with Kroll's acid and cleaning with copious amounts of distilled water. The dried electrodes were then suspended in a reaction vessel containing $10 \mathrm{mg}$ of 2,2,4,5-tetracyanobenzene which was evacuated and sealed. After reaction at $300-400^{\circ} \mathrm{C}$ for 24 hours, dark blue phthalocyanine surfaces were obtained. Nickel sponge/phthalocyanine electrodes were prepared in the same manner.

Nafion ${ }^{\circledR}$-coated electrodes were prepared by one of two procedures. In the first, electrodes were coated with a Nafion ${ }^{\circledR}$ film by evaporation of $10-20 \mathrm{~mL}$ of a commercial (Aldrich) $5 \mathrm{wt} \%$ solution using a hair dryer and then cycled through the CoIIII-cyclam couple in $1 \mathrm{M} \mathrm{NaOH}$ containing $5 \mathrm{mM}$ CoII-cyclam at slow sweep rate (typically 40 $\mathrm{mV} / \mathrm{s})$. The electrode was then removed from the solution containing the electrocatalyst, rinsed with distilled water and transferred to the solution under investigation. In the second procedure, a $2 \mathrm{mM}$ solution of [CoIII $($ cyclam $\left.) \mathrm{Cl}_{2}\right] \mathrm{Cl}$ in ethanol was diluted with an equal volume of the $5 \mathrm{wt} \%$ Nafion ${ }^{\circledR}$ solution. This solution was then used to coat the electrodes in the above manner. The latter electrodes tended to give greater sensitivity to nitrate, presumably owing to the thinner coatings. Profilimetry on dry films cast on smooth glass substrates indicated that the films were quite rough with average thicknesses on the order of 100 to $300 \mathrm{~nm}$.

\section{Instrumentation}

A variety of dc power supplies were used by the various laboratories in which the experimental work was carried out. Constant potential and current electrolyses in conjunction with volumetric tests were performed with either a BAS-100 Electrochemical Analyzer or a P.A.R. Model 173 potentiostat equipped with a Model 179 digital coulometer. Constant current electrolyses were performed with the Model 173 potentiostat/galvanostat. A Pine Instrument Co. bipotentiostat and rotators (Model Nos. RDE4 and PIR) were used for the ring-disk experiments. Ultraviolet/visible absorption spectra were obtained on a Cary Model 219 spectrophotometer. Samples of the Nafion ${ }^{\circledR}$ Type 324 and 417 membranes were irradiated in a Gammacell ${ }^{60} \mathrm{Co}$ gamma radiation field of $4.7 \pm 0.6 \times 10^{4} \mathrm{rad} / \mathrm{hr}$ for up to 8 hours.

\section{Membrane Resistance Testing}

Irradiated Nafion ${ }^{\circledR}$ Type 324 and 417 membranes were tested for changes in resistance in a glass $\mathrm{H}$-cell fitted with Luggin capillary probes extending to within $1 \mathrm{~mm}$ of either side of the membrane. Saturated calomel electrode (SCE) reference electrodes in the Luggin chambers measured the potential difference corresponding to the potential drop across the membrane as a function of current density. Electrodes were platinum flags placed well away from the membrane and Luggin probes. The electrolyte was $2 \mathrm{M}$ sulfuric acid held at $40 \pm 1^{\circ} \mathrm{C}$. The current was slowly increased from $0-2.25 \mathrm{~A}\left(0-5000 \mathrm{~A} / \mathrm{m}^{2}\right)$ at a rate of $1.4 \mathrm{~mA} /$ second. Current and potential were sampled every 24 seconds. The entire test lasted 27 minutes. 


\section{RESULTS AND DISCUSSION}

\section{Knolls Atomic Power Laboratory and Oak Ridge National Laboratory Studies} Electrolytic treatment of radioactive wastes was first reported by Alter and coworkers at the Knolls Atomic Power Laboratory (Schenectady, NY) in 1957 [5]. Alkaline sodium nitrate solutions were reported to be reduced to a mixture of nitrite, ammonia, nitrogen, and nitrous oxide in an undivided cell using a steel cathode. The current efficiency was not affected by changes in either the current density or temperature. However, the cell resistance was significantly affected by the electrode spacing. In addition to nitrate destruction, ruthenium was reported to be reduced and deposited on the cathode.

In follow-up studies at Oak Ridge National Laboratory, Messing and Higgins reported on the reduction of ruthenium and nitrate in three different reactor designs as a function of temperature, cell potential, current density, solution concentration and stirring rate [6]. Significant factors affection the deposition of ruthenium were temperature, cathode area, current density, and concentration. Factors affecting the reduction of nitrate included: current density, concentration, and stirring rate. A major objective of this work was to determine which conditions, if any, would maximize the deposition of ruthenium and minimize the destruction of nitrate.

\section{Feasibility Studies at the International Hydronics Corporation [7-10]}

A patented process was developed by the International Hydronics Corporation (IHC) for the destruction of nitrate in alkaline waste solutions produced from the manufacturing of nickel-cadmium battery plates [7]. In this process, the anode material is composed of a metal or alloy of nickel, cobalt, or iron and the cathode material is composed of a metal or alloy of nickel, cobalt, iron, cadmium, or copper. Significant operating parameters included electrode spacing and current density in addition to the electrode material.

A series of tests was carried out with SRS Decontaminated Salt Solution simulant at the International Hydronics Corporation (IHC) in Rocky Hill, NJ to establish the feasibility of electrochemically destroying the nitrate and nitrite in alkaline salt solutions. These tests were carried out in a undivided, single-cell electrochemical reactor, IHC-1, without external mixing (mixing only being provided by the evolution of gases produced at each electrode). The current efficiency for the destruction of nitrate and nitrite was considerably lower in tests with the SRS-1 simulant (10-20\%) than in previous experience with battery plating solutions (70-95\%). Testing identified that the presence of chromate was responsible for the very low current efficiencies. In addition to low current efficiency, a dark brown-black deposit was formed on the cathode.

The current efficiency could be increased by the addition of bismuth compounds such as $\mathrm{NaBiO}_{3}$ and $\mathrm{Bi}\left(\mathrm{NO}_{3}\right)_{3}$ and reversal of the cell polarity. It was believed that the addition of the bismuth compound precipitated a large fraction of the chromate as the bismuth hydroxy dichromate salt, $\mathrm{Bi}(\mathrm{OH})_{2} \mathrm{Cr}_{2} \mathrm{O}_{7}$. Isolation and analysis of solids produced during experiments confirmed the presence of $\mathrm{Bi}$ and $\mathrm{Cr}$.

Over time, the effectiveness of the bismuth salt addition decreases as evidenced by low current efficiencies. Reversal of the cell potential at this point in time restored good current efficiencies. Reversal of the cell polarity removed the dark brown-black deposit of chromium hydroxide on the cathode, that is believed to be inhibiting the reduction of nitrate and nitrite.

Current density and electrode spacing were found to have only minor effects on the current efficiency. At $540 \mathrm{~A} / \mathrm{m}^{2}$, the steady-state temperature in the IHC-1 cell was $75^{\circ} \mathrm{C}$ 
compared to about $100^{\circ} \mathrm{C}$ at $1100 \mathrm{~A} / \mathrm{m}^{2}$. Increasing the electrode spacing from $2.9 \mathrm{~cm}$ to $5.7 \mathrm{~cm}$ decreased slightly the current efficiency. The concentration of hydroxide upon complete destruction of the nitrate and nitrite was generally about $5.0 \mathrm{M}$. At the higher current density (higher temperature), the final hydroxide concentration was about $6.4 \mathrm{M}$, due to larger evaporative losses and more water electrolysis.

Phase II testing at IHC was carried in the larger multicell reactor, IHC-2. The electrode spacing in the IHC-2 reactor is $5.1 \mathrm{~cm}$. Initially, the multicell reactor was run in a bipolar configuration in a static mode. Current efficiencies averaged $58.4 \pm 4.6 \%$. As in the smaller single cell tests, current efficiencies decreased with time. Reversal of the cell polarity restored current efficiencies temporarily. Addition of bismuth salts also recovered current efficiencies when polarity reversal did not recover the current efficiency.

Over the course of the bipolar runs a brown deposit was formed at the anode. This deposit was determined to be $\mathrm{B}_{2} \mathrm{O}_{5}$. The deposit inhibits the anode reactions as evidenced by noticeable decrease in gas evolution rate. Removal of the deposit restored the reaction rate.

Monopolar runs were also carried out in the multicell reactor. Much higher current efficiencies $(97.0 \pm 18.6 \%$ ) were observed compared to the previous bipolar tests. As in the bipolar tests, polarity reversal and the addition of bismuth salts were required to maintain high current efficiencies. In contrast to the bipolar tests, no deposit formed on the anodes. For the monopolar configuration, the total power consumed in kwhr per kilogram of sodium nitrate average $6.8 \pm 1.5$ compared to $11 \pm 0.7 \mathrm{kw}-\mathrm{hr} / \mathrm{kg}$ for bipolar cell operation.

Inspection of electrodes after each of the tests indicated that the nickel anode did suffer some localized attack. A small amount of solids were produced during the tests primarily as a result of the addition of bismuth salts. The settled sludge volume varied from 0.7 to $0.9 \%$ of the starting salt solution volume. On a dried solids basis, the solids were comprised of $71.3 \%$ bismuth, $15.0 \%$ nickel, and $0.3 \%$ chromium.

\section{Electroanalytical Studies at the University of Tennessee [11-16]}

\subsection{Bulk Electrolysis Tests}

Constant potential coulometry was performed at platinum, nickel, and platinized nickel electrodes under a variety of conditions using a simplified alkaline salt solution having the composition given in Table II. A summary of the results are given in Table III. Most of the electrolyses were carried out with a divided glass cell using a Nafion ${ }^{\circledR}$ membrane to separate the anodic and cathodic reactions.

\section{Table II. Composition of the Simplified Alkaline Salt Solution}

Species

$\mathrm{NaOH}$

$\mathrm{Na}_{2} \mathrm{CO}_{3}$

$\mathrm{NaNO}_{3}$

$\mathrm{NaNO}_{2}$
Concentration (M)

$1.0-3.0$

$0-0.25$

$0-0.025$

$0-0.025$ 


\section{Table III. Constant Potential Electrolyses of Alkaline Nitrate/Nitrite Solutions} at $80^{\circ} \mathrm{C}$.

\begin{tabular}{|c|c|c|c|c|c|c|c|c|}
\hline No. & $\begin{array}{l}\text { Electrode } \\
\text { material }\end{array}$ & $\begin{array}{c}E_{\text {app! }} \\
\text { (V vs. SCE) }\end{array}$ & Atmosphere & $\begin{array}{c}\text { Amount } \\
\text { of } \mathrm{NaNO}_{3} \\
\text { reduced } \\
\text { (mg) }\end{array}$ & $\begin{array}{l}\text { Charge } \\
\text { required } \\
\text { (C) }\end{array}$ & $\begin{array}{l}\text { Current } \\
\text { efficiency } \\
(\%)\end{array}$ & $\begin{array}{l}\text { \% Decr. } \\
\text { in 1h }\end{array}$ & Product \\
\hline $\begin{array}{l}1 \\
2 \\
3 \\
4 \\
5 \\
6\end{array}$ & $\begin{array}{l}\mathrm{Ni} \\
\mathrm{Pt} \\
\mathrm{Pt} \\
\mathrm{Pt} \\
\mathrm{Ni}(\mathrm{Pt}) \\
\mathrm{Ni}(\mathrm{Pt})\end{array}$ & $\begin{array}{c}0.5 \mathrm{~V} \leftrightarrow 1.35 \mathrm{~V}^{\mathrm{a}} \\
0.5 \mathrm{~V} \leftrightarrow 1.15 \mathrm{~V} \\
-1.2 \mathrm{~V} \\
-1.2 \mathrm{~V} \\
-1.2 \mathrm{~V} \\
-1.2 \mathrm{~V}\end{array}$ & $\begin{array}{l}\mathbf{N}_{2} \\
\mathbf{N}_{2} \\
\mathbf{N}_{2} \\
\text { Air } \\
\mathbf{N}_{2} \\
\mathbf{N}_{2}(99 \%) \\
\mathrm{O}_{2}(\mathbf{1} \%)\end{array}$ & $\begin{array}{c}99 \\
36.3 \\
99.4 \\
112 \\
44 \\
71\end{array}$ & $\begin{array}{r}562 \\
293 \\
702 \\
1196 \\
296 \\
547\end{array}$ & $\begin{array}{l}62 \\
70 \\
80 \\
53 \\
86 \\
74\end{array}$ & $\begin{array}{l}\overline{-} \\
\overline{48} \\
48 \\
71\end{array}$ & $\begin{array}{c}\mathrm{N}_{2} \\
\mathrm{NO}_{2}{ }^{-}>\mathrm{N}_{2} \\
\mathrm{NO}_{2}^{-}>\mathrm{N}_{2} \\
\mathrm{~N}_{2}>>\mathrm{NO}_{2} \\
\mathrm{~N}_{2}>\mathrm{NO}_{2} \\
\mathrm{~N}_{\mathrm{R}} \approx \mathrm{NO}_{2}\end{array}$ \\
\hline 7 & $\mathrm{Ni}(\mathbf{P t})$ & $-1.2 \mathrm{~V}$ & $\mathrm{~N}_{2}(95 \%)$ & 90 & 803 & 63 & 90 & $\mathrm{~N}_{2}$ \\
\hline 8 & $\mathrm{Ni}(\mathrm{Pt})$ & $-1.2 \mathrm{~V}$ & $\begin{array}{l}\mathrm{O}_{2}(5 \%) \\
\mathrm{N}_{2}(91 \%) \\
\mathrm{O}_{2}(9 \%)\end{array}$ & 90 & 1620 & 31 & 88 & $\mathrm{~N}_{2}$ \\
\hline 9 & $\mathrm{Ni}(\mathrm{Pt})$ & $-1.2 \mathrm{~V}$ & $\begin{array}{l}N_{2}(83 \%) \\
\mathrm{O}_{2}(17 \%)\end{array}$ & 84 & 1751 & 27 & 84 & $\mathrm{~N}_{2}$ \\
\hline $\begin{array}{l}10 \\
11 \\
12 \\
13 \\
14\end{array}$ & $\begin{array}{l}N i(P t) \\
N i(P t) \\
N i(P t) \\
N i(P t) \\
N i(P t)\end{array}$ & $\begin{array}{l}-1.2 \mathrm{~V} \\
-1.1 \mathrm{~V} \\
-1.0 \mathrm{~V} \\
-0.9 \mathrm{~V} \\
-1.1 \mathrm{~V}\end{array}$ & $\begin{array}{l}\text { Air } \\
\text { Air } \\
\text { Air } \\
\text { Air } \\
\mathrm{N}_{2}(70 \%) \\
\mathrm{O}_{2}(30 \%)\end{array}$ & $\begin{array}{r}91 \\
99 \\
107 \\
28 \\
100\end{array}$ & $\begin{array}{l}988 \\
711 \\
740 \\
168 \\
718\end{array}$ & $\begin{array}{l}53 \\
79 \\
82 \\
94 \\
79\end{array}$ & $\begin{array}{l}54 \\
92 \\
67 \\
17 \\
87\end{array}$ & $\begin{array}{l}\mathbf{N}_{2} \\
\mathbf{N}_{2} \\
\mathbf{N}_{2} \\
\mathbf{N}_{2} \\
\mathbf{N}_{2}\end{array}$ \\
\hline 15 & $\mathrm{Ni}(\mathrm{Pt})$ & $-1.0 \mathrm{~V}$ & $\begin{array}{l}\mathrm{N}_{2}(70 \%) \\
\mathrm{O}_{2}(30 \%)\end{array}$ & 69 & 541 & 73 & 52 & $\mathrm{~N}_{2}$ \\
\hline 16 & $\mathrm{Ni}(\mathrm{Pt})$ & $-0.9 \mathrm{~V}$ & $\begin{array}{l}\mathrm{N}_{2}(70 \%) \\
\mathrm{O}_{2}(30 \%)\end{array}$ & 53 & 266 & 79 & 20 & $\mathrm{~N}_{2}$ \\
\hline 17 & $\mathrm{Ni}(\mathrm{Pt})$ & $\begin{array}{l}-1.1 \mathrm{~V} \\
\left(54^{\circ} \mathrm{C}\right)\end{array}$ & $\begin{array}{l}\mathrm{N}_{2}(70 \%) \\
\mathrm{O}_{2}(30 \%)\end{array}$ & 53 & 432 & 78 & 88 & $\mathrm{~N}_{2}$ \\
\hline 18 & $\mathrm{Ni}(P t)$ & $\begin{array}{l}-1.1 \mathrm{~V} \\
\left(25^{\circ} \mathrm{C}\right)\end{array}$ & $\begin{array}{l}\mathrm{N}_{2}(70 \%) \\
\mathrm{O}_{2}(30 \%)\end{array}$ & 36 & 314 & 64 & 14 & $\mathrm{~N}_{2}$ \\
\hline 19 & $\mathrm{Ni}$ & $-1.3 \mathrm{~V}$ & $\begin{array}{l}\mathrm{N}_{2}(70 \%) \\
\mathrm{O}_{2}(30 \%)\end{array}$ & 14 & 578 & 13 & 5 & $\mathrm{~N}_{2}>\mathrm{NO}_{2}$ \\
\hline $\begin{array}{l}20 \\
21\end{array}$ & $\begin{array}{l}\mathrm{Ni}(\mathrm{Pt}) \\
\mathrm{Ni}(\mathrm{Pt})\end{array}$ & $\begin{array}{l}-1.2 \mathrm{~V} \\
-1.1 \mathrm{~V}\end{array}$ & $\begin{array}{l}\mathrm{N}_{2} \\
\text { Air }\end{array}$ & $\begin{array}{l}114^{\mathrm{b}} \\
100^{\mathrm{b}}\end{array}$ & $\begin{array}{l}540 \\
491\end{array}$ & $\begin{array}{l}88 \\
85\end{array}$ & $\begin{array}{l}94 \\
97\end{array}$ & $\begin{array}{l}\mathrm{N}_{2} \\
\mathrm{~N}_{2}\end{array}$ \\
\hline
\end{tabular}

Electrolysis at $0.5 \mathrm{~V}$ for $20 \mathrm{~s}$, followed by electrolysis at $-1.35 \mathrm{~V}$ for $100 \mathrm{~s}$.

b Weight of $\mathrm{NaNO}_{2}$

Figure 1 shows the time dependence of the nitrate and nitrite concentrations for a typical experiment in which a nitrite intermediate chromatographic peak appears during the course of an electrolysis. The charge passed (open circles) is also shown. Coulometric current efficiencies based on the five-electron reduction to dinitrogen $\left(\mathrm{N}_{2}\right)$ were quite high, ranging up to ca. $90 \%$ in some experiments. At short times (less than $20 \%$ electrolysis), close to $100 \%$ current efficiencies were obtained. In most of the electrolyses a nitrite intermediate peak was evident, although further reduction was always observed. No other peaks appeared in the ion chromatograms. 
Figure 1. Variation of Nitrate and Nitrite Concentrations During Electrolysis of Sodium Nitrate in $3 \mathrm{M} \mathrm{NaOH}, 0.25 \mathrm{M} \mathrm{Na} \mathrm{CO}_{3}$ at a Platinized Nickel Electrode, $-1.2 \mathrm{~V}$ vs. SCE, $80^{\circ} \mathrm{C}$

$$
\text { Symbols: } o=\text { charge }\left(\text { coulombs), } \bullet=\left[\mathrm{NO}_{3}^{-}\right](\mathrm{M}), \Theta=\left[\mathrm{NO}_{2}{ }^{-}\right](\mathrm{M})\right.
$$

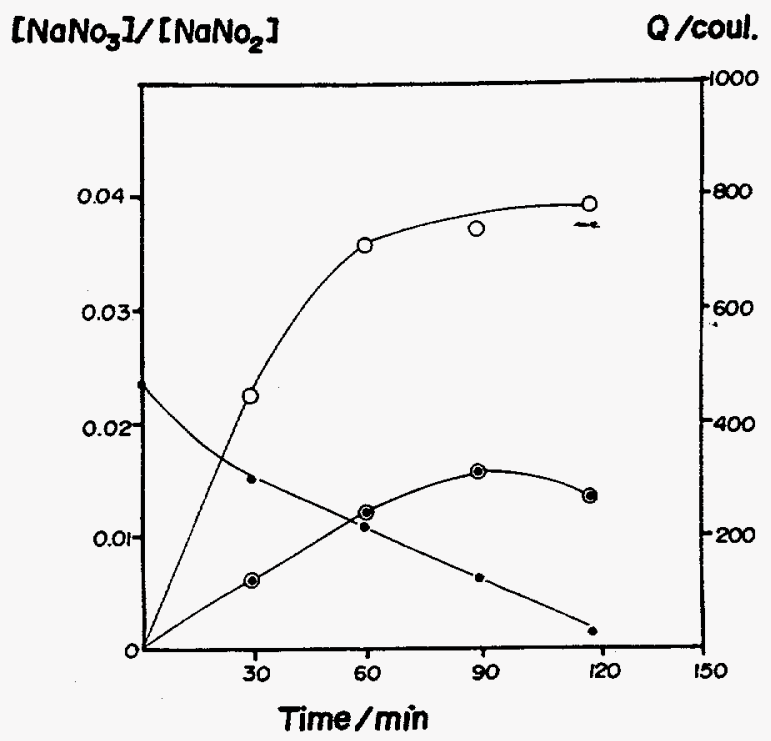

Qualitative identification of $\mathrm{N}_{2}$ as the major gaseous electrolysis product was achieved by mass spectroscopy using isotopically labeled ${ }^{15} \mathrm{NO}_{3}{ }^{-}$. In these experiments the cathode was inserted in an inverted collection tube in a quiet solution that had been flushed with argon prior to electrolysis. The gas produced at the cathode was collected by displacement of the aqueous $\mathrm{NaOH}$ solution, transferred to an evacuated sampling vessel, and injected directly into the ionization chamber of a mass spectrometer. After correction for the background signal at $\mathrm{m} / \mathrm{e}=28,29$, and 32 , the ratio of the signals for ${ }^{15} \mathrm{~N}^{14} \mathrm{~N}$ and ${ }^{14} \mathrm{~N}_{2}$ was approximately that expected for the isotopic content of the electrolysis solution. Accordingly a solution containing a 0.186 molar ratio of ${ }^{15} \mathrm{NO}_{3}{ }^{-}$to ${ }^{14} \mathrm{NO}_{3}{ }^{-}$gave 0.36 for the $\mathrm{m} / \mathrm{e}=29$ to 28 ratio. The expected ratio is 0.373 . This unequivocally demonstrates that the $\mathrm{N}_{2}$ formed by the electrolysis is derived from the nitrate ion. Weak signals attributed to ammonia were also seen. No peak at $\mathrm{m} / \mathrm{e}=44$ for $\mathrm{N}_{2} \mathrm{O}$ was observed, although this species has been reported in the literature.

Increasing amounts of ammonia were observed upon an increase in the cathodic current density in bulk electrolysis experiments carried out at constant current. At current densities $\leq 1070 \mathrm{~A} / \mathrm{m}^{2}$, nitrogen is the major electrolysis product. At $4660 \mathrm{~A} / \mathrm{m}^{2}$ ammonia was found to be the major electrolysis product. Also, the amount of ammonia was observed to increase during the course of the electrolyses.

Current efficiencies, $\left(\mathrm{Q} / \mathrm{Q}_{\mathrm{T}}\right) \times 100$ in Table I, were calculated from the charge, $\mathrm{Q}$, assuming that the products of the electrolyses were nitrite ion, a two-electron process, and dinitrogen, a five-electron process, using equation 11 to calculate the theoretical amount 


$$
\mathrm{Q}_{\mathrm{T}}=5 \mathrm{~F}\left(\mathrm{~A}_{\mathrm{O}}-\mathrm{A}_{\mathrm{t}}\right)-3 \mathrm{FB}_{\mathrm{t}}
$$

of charge for the nitrate reduction. In this equation $A_{O}$ is the initial amount of nitrate in moles and $A_{t}$ and $B_{t}$ are the molar amounts of nitrate and nitrite, respectively, present at the end of the electrolysis. These quantities were determined by ion chromatography. It can be noted from the data in Table III that observation of a nitrite intermediate was favored when platinum electrodes were employed. The platinized nickel electrodes gave greater current densities based on geometrical electrode area and more efficient reduction to nitrogen gas.

Several preliminary electrolyses at constant current were performed in the presence of ruthenium added to the solution in the form of the disodium salt of hydroxynitrosyltetranitrotuthenium(II), $\mathrm{Na}_{2}\left[\mathrm{RuNO}\left(\mathrm{NO}_{2}\right)_{4} \mathrm{OH}\right]$. Higher conversion rates of nitrate and nitrite into ammonia were observed in these experiments. Over the course of the electrolysis, elemental ruthenium deposited on the nickel cathode. Since nitro and nitrosyl ruthenium complexes are known to undergo facile electrochemical reduction to ammine complexes [17], the ruthenium complex or the ruthenium deposit on the cathode may in part be providing for a more facile mechanism for the reduction to ammonia.

Since previous studies were not concerned with the removal of dissolved oxygen gas in the electrolysis cells, several experiments were performed in which oxygen was mixed with the nitrogen gas which flushed the cathode compartment. It can be noted that not only was oxygen not removed from the cells in previous studies, but the solutions were saturated with the oxygen formed at the anodes. Since the reduction potential of oxygen is considerably less than that of the cathode during the reduction of nitrate, reduction of oxygen is likely to be involved in the cell process.

Increasing the percent oxygen content has two effects. The current efficiencies decrease, presumably due to the concurrent reduction of oxygen, and the rate of nitrate reduction, as measured by the percent nitrate reduced in 1 hour of electrolysis, increases. The increase in significant, from ca. $45 \%$ for pure nitrogen to $90 \%$ for $5 \%$ oxygen in the gas stream. Several experiments were performed to see if hydrogen peroxide (e.g., $\mathrm{H}_{2} \mathrm{O}_{2}$ ) generated by the two-electron reduction of oxygen

$$
\mathrm{O}_{2}+\mathrm{H}_{2} \mathrm{O}+2 \mathrm{e}^{-}=\mathrm{HO}_{2}^{-}+\mathrm{OH}^{-}
$$

could be responsible for the increased rate of nitrate reduction (equation 12). However, addition of aliquots of $30 \% \mathrm{H}_{2} \mathrm{O}_{2}$ solution to alkaline solutions of $\mathrm{NaNO}_{3}$ and $\mathrm{NaNO}_{2}$ at $80^{\circ} \mathrm{C}$ did not result in the decrease of the ion chromatographic peaks for nitrate or nitrite. These results suggest an electrocatalytic role for the superoxide anion, $\mathrm{O}_{2}^{-}$, in the reduction process.

Figure 2 shows the concentration changes of nitrate, nitrite and ammonia as a function of current density for a series of 60 - min constant current electrolyses at different current densities. Product distribution profiles similar to Figure 2 were observed for electrolyses with different electrode materials including nickel, iron, phthalocyanine coated iron, and zinc. Dinitrogen gas, which was detected by mass spectrometry but not quantitated, and nitrous oxide are the other products assumed to be formed in these electrolyses to account for a mass balance on nitrogen. 
Figure 2. Variation of Nitrate (A), Nitrite (B), and Ammonia (C) Concentrations During Constant Current Electrolysis Between a Lead Cathode and Nickel Anode

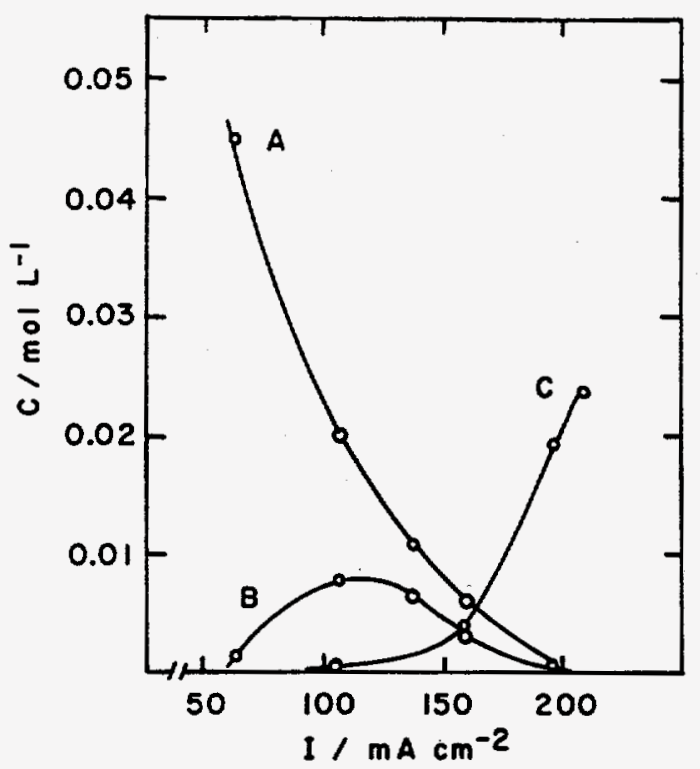

The mechanism of the nitrate reduction is clearly complex. It can be noted that at the more negative potentials the 'background' currents at the electrodes under study are large. Since high current efficiencies are obtained based on the measured amounts of nitrite ion, ammonia and dinitrogen (the latter obtained by difference), adsorbed hydrogen or hydride intermediates are probably involved in the electrode process.

The effect of electrode material on the reduction of the nitrate concentration is shown in Figures 3 and 4 . The most rapid reduction of the nitrate levels was found for the chemically active electrode materials. The effect of phthalocyanine modification shown in Figure 4 is interesting. Coating a porous nickel electrode with phthalocyanine renders it less active toward nitrate reduction, while the iron electrode appears to be activated. It should also be noted that significant weight losses were again observed for iron cathodes when they were not coated with the phthalocyanine layer. 
Figure 3. Effect of Electrode Material on the Reduction of Nitrate During Constant Current Electrolysis at $1730 \mathrm{~A} / \mathrm{m}^{2}$ in $3.0 \mathrm{M} \mathrm{NaOH}$ and $0.25 \mathrm{M} \mathrm{Na}_{2} \mathrm{CO}_{3}$

Working electrode: (A) Nickel (B) Porous Nickel, (C) Iron (D) Lead, (E) Zinc

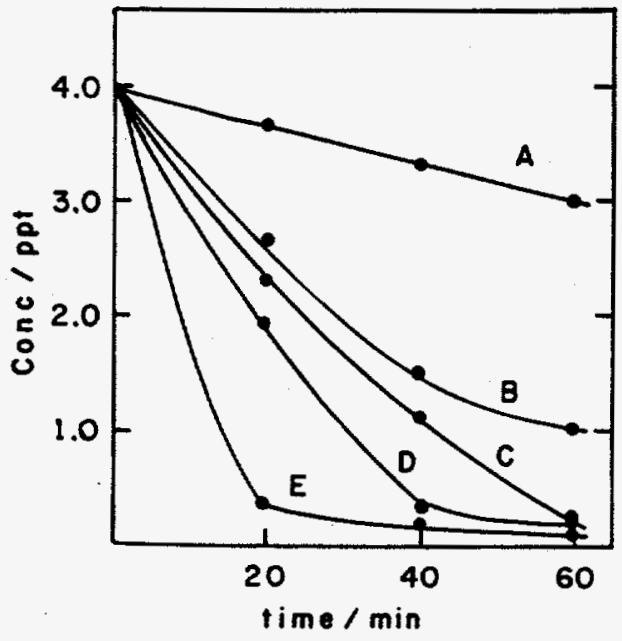

Figure 4. Effect of Phthalocyanine (PC) Modication on the Reduction of Nitrate During Constant Current Electrolysis at $1730 \mathrm{~A} / \mathrm{m}^{2}$ in $3.0 \mathrm{M} \mathrm{NaOH}$ and $0.25 \mathrm{M} \mathrm{Na}_{2} \mathrm{CO}_{3}$

Working electrode: (A) Nickel, (B) Porous Nickel/PC, (C) Porous Nickel, (D) Iron, (E) Iron/PC

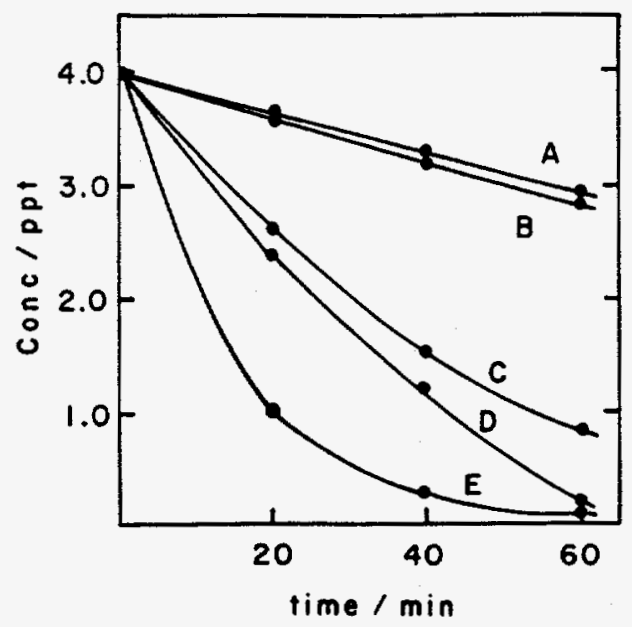




\subsection{Cyclic Voltammetry}

Only non-ideal cyclic voltammograms of alkaline nitrate and nitrite solutions were obtained under experimental conditions similar to that employed in the bulk electrolysis tests. Careful attention to electrode pretreatment procedures was necessary to obtain reproducible behavior. The cyclic voltammetric results only permitted the qualitative conclusion that surface phenomena, e.g., adsorption processes and reduction of oxide films, play important roles in the electrode reaction for the reduction of nitrate/nitrite in strongly alkaline solutions.

\subsubsection{Reduction of Nitrite}

Figure 5 shows a cyclic voltammogram obtained at a Pt electrode in $0.015 \mathrm{M} \mathrm{NaNO}, 1 \mathrm{M}$ $\mathrm{NaOH}$ at room temperature in an unstirred solution. On the forward sweep, a nearly symmetrical nitrite reduction peak appears at $-0.84 \mathrm{~V}$ vs. SCE. On the reverse sweep, the cathodic current increases, roughly retracing the forward current, and exhibits a cathodic peak with a pronounced shoulder. This highly unusual voltammetric pattern was reproducible and was observed for both nitrate and nitrite solutions at platinum electrodes. The peak current on the negative going sweep was proportional to $\mathrm{v}^{0.7}$ over the sweep rate (v) range, $0.01-2 \mathrm{~V} / \mathrm{s}$. This behavior is indicative of a complex electrode process that is not purely diffusion controlled. The wave at ca. $-0.3 \mathrm{~V}$ in Figure 5, which does not appear to be associated with the reduction of nitrite ion, is believed to be due to reduction of an oxide film or solution impurities (e.g., residual oxygen). This wave was enhanced when the electrode was held at potential more positive than $0.5 \mathrm{~V}$ vs. SCE. The peak current was markedly dependent on temperature, increasing by a factor of seven over the temperature range $20-9.5^{\circ} \mathrm{C}$. The plot of $\ln i_{p} v s .1 / T$ was nonlinear, which is further indication that a simple diffusion controlled process was not operative. The concentration dependence of the nitrite peak current which was nonlinear at low concentrations. The nitrite reduction current was not a strong function of the $\mathrm{NaOH}$ concentration.

Figure 5. Cyclic Voltammogram for the Reduction of $0.015 \mathrm{M}$ Nitrite at $23^{\circ} \mathrm{C}$ in $1 \mathrm{M}$ $\mathrm{NaOH}$ (Pt electrode, sweep rate $=50 \mathrm{mV} / \mathrm{sec}$ )

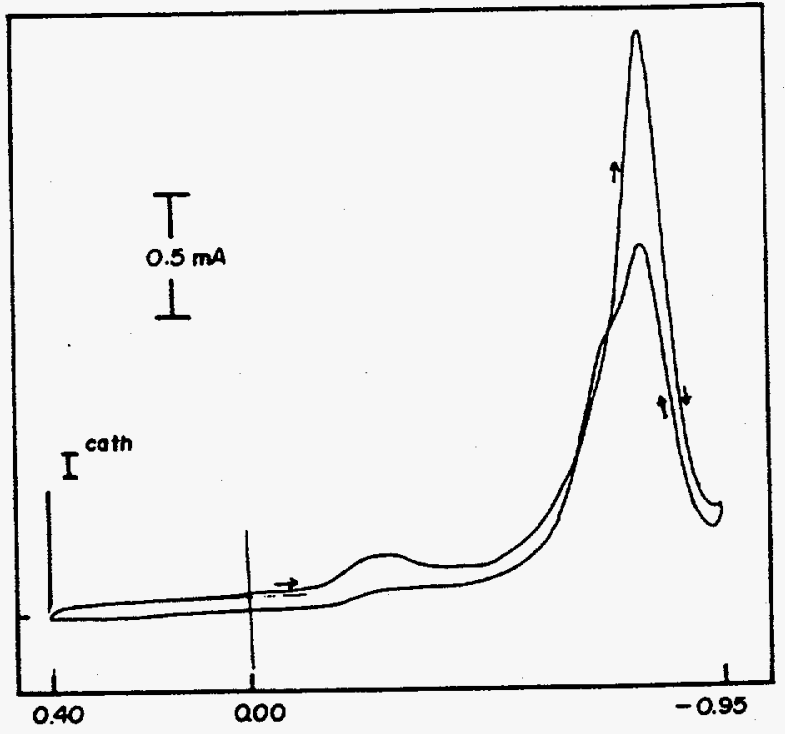

E/Volt vs S.C.E. 
Interestingly, the nitrite peak current was found to be dependent on the potential selected to poise the electrode prior to initiation of the negative going potential sweep, the 'activation potential," and the length of time the electrode was maintained at this potential. Potentiostating the electrode at $0.5 \mathrm{~V}$ vs. SCE for about 60 seconds produces an increase in the cathodic reduction peak for nitrite of almost a factor of 10 . The peak current is also enhanced by simple immersion of the platinum electrode in the $\mathrm{NaNO}_{2}$ solution at open circuit, but longer times are required to enhance the current to the same level.

\subsubsection{Reduction of nitrate}

At room temperature and concentration less than ca. $0.01 \mathrm{M}$, cyclic voltammograms of nitrate at polished platinum electrodes showed very little indication of electroactivity due to a diffusion controlled process. At elevated temperature, however, a small reduction wave was evident in the cyclic voltammograms that had peak potentials and wave characteristics on the forward and reverse potential sweeps quite similar to the above description of the nitrite voltammetry. These peak currents, which increased with $\mathrm{NaNO}_{3}$ concentration, are attributed to reduction of a nitrite intermediate in the nitrate and nitrite reductions. The possibility of a nitrite impurity in the $\mathrm{NaNO}_{3}$ at a sufficient level to give this behavior is discounted by the absence of a nitrite peak in the ion chromatograms of the initial nitrate solutions.

At more negative potential and high concentrations of nitrate, a broad voltammetric wave due to nitrate reduction was observed (see Figure 6). The peak currents were dependent on the initial potential in a fashion similar to the nitrite voltammetry, but the effect was less dramatic. Also, the currents were dependent on the $\mathrm{NaOH}$ concentration, increasing with $\mathrm{NaOH}$ concentration up to $12 \% \mathrm{NaOH}$ (ca. $3.4 \mathrm{M}$ ) at which point the currents became independent of percent $\mathrm{NaOH}$. At $20 \% \mathrm{NaOH}$, the currents did not vary with the carbonate content over the range 0 to $3 \mathrm{M} \mathrm{Na}_{2} \mathrm{CO}_{3}$. It is noteworthy that nitrate is reduced at more negative potentials than nitrite under voltammetric conditions in accord with the bulk electrolyses where nitrite ion was found to be an intermediate in the electrode process.

Figure 6. Cyclic Voltammogram of $0.59 \mathrm{M} \mathrm{NaNO}{ }_{3}$ in $3 \mathrm{M} \mathrm{NaOH}$ and $0.25 \mathrm{M} \mathrm{Na} \mathrm{CO}_{3}$ at $80^{\circ} \mathrm{C}$ (Pt electrode, sweep rate $=50 \mathrm{mV} / \mathrm{sec}$ ).

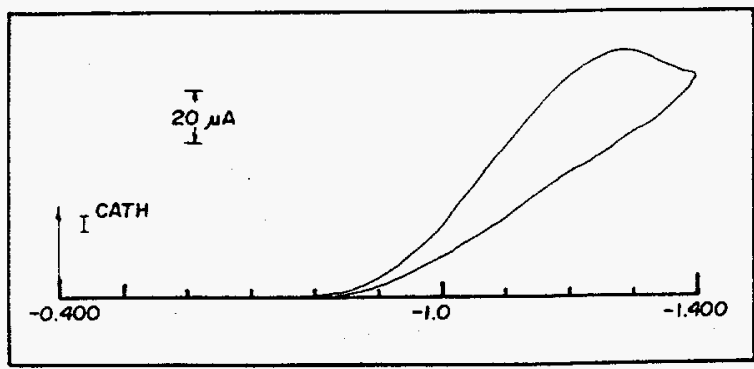

E/Volt vs S.C.E. 


\subsection{Electrocatalysis Studies}

Transition-metal macrocyclic amine complexes based on ligands such as $1,4,8,11$ tetraazacyclotetradecane (cyclam), have the property of catalyzing a variety of redox processes of a remarkable diversity. Electrocatalytic reductions of dioxyen, carbon dioxide, the $\mathrm{N}-\mathrm{O}$ bond in nitrate and nitrite, and carbon-halogen bonds have been reported. Studies were undertaken to determine the compatibility of the metal-cyclam electrocatalyzed cycle for the reduction of nitrate under the strongly alkaline conditions that are encountered in the treatment of nuclear waste solutions.

\subsubsection{Characterization of $\mathrm{CO}_{\mathrm{III}}$ (cyclam) in Alkaline Solutions}

The 14 membered cyclic amine macrocyclic ligand and its metal complexes have not been well studied in strong base. Accordingly, cyclic voltammograms and visible absorption spectra of solutions of $\left[\mathrm{Co} \mathrm{II}_{(\mathrm{cyclam} \mathrm{Cl}}\right]^{+}$were obtained as a function of added $\mathrm{NaOH}$ solution. The results show that the quasi-reversible $\mathrm{Co}$ III/I (cyclam) couple is strongly $\mathrm{pH}$-dependent and moderately complex.

Addition of small amounts of $\mathrm{NaOH}$ to the emerald green solutions of the transdichlorocyclamcobalt(III) complex ( $\max =433,633 \mathrm{~nm}$; c.f. $440,640 \mathrm{~nm}$ ) causes marked changes in the visible absorption spectrum. For solutions with up to less than 1 equivalent of base, isosbestic points are seen at 429 and $609 \mathrm{~nm}$. The isosbestic points are lost as more base is added, indicating the existence of more than two species in equilibrium, and at 2 equivalents, the spectrum becomes independent of base up to $3 \mathrm{M}$ $\mathrm{NaOH}$. This behavior is consistent with the known rapid base-catalyzed hydrolysis of the trans-dichloro complex and formation of the trans-dihydroxo complex. The absorption spectrum of the solution exhibits maxima at $387 \mathrm{~nm}\left(\mathrm{a}=59.9 \mathrm{M}^{-1} \mathrm{~cm}^{-1}\right)$ and is assigned to the trans-dihydroxycyclamcobalt(III) complex.. The shift of $\lambda_{\max }$ to a lower value is consistent with formation the dihydroxy complex according to the spectrochemical series. Beer's law is obeyed up to a concentration of $0.015 \mathrm{M}$. Neutralization of the solution with $\mathrm{HClO}_{4}$ produces a pale green solution that has an absorption spectrum which matches the reported spectrum of the known trans-CoII (cyclam) $\left(\mathrm{H}_{2} \mathrm{O}\right)_{2}{ }^{3+}$ species.

The cyclic voltammetry of the Colli (cyclam) complex in base is more intricate than suggested by the spectrophotometric titrations. Identical voltammograms were obtained when the trans-[COIII $\left(\text { cyclam } \mathrm{Cl}_{2}\right]^{+}$complex was either added directly to the $\mathrm{NaOH}$ solution or when the chloride ligands were exchanged prior to the addition of the base by passage of the complex through an anion-exchange column in the hydroxide form. Similar voltammograms were obtained at mercury, gold, lead, and silver electrodes, although the degree of reversibility was dependent on the electrode material to a certain extent. The anodic segment of the voltammogram indicates a two-step process, which becomes more evident at faster sweep rates. The peak current ratio, $\mathrm{i}_{\mathrm{p}}$ anod $/ \mathrm{ip}$ cath, is significantly less than unity. Both the shape and the position of the $\mathrm{Co}$ IIIII (cyclam) voltammetric wave are markedly dependent on the solution $\mathrm{pH}$ in the presence of excess base.

3.3.2. Cyclic Voltammetry of $\mathrm{Co}$ III (cyclam)/Nitrate and $\mathrm{Co}_{0} \mathrm{II} /$ cyclam)/Nitrite Solutions In agreement with the results of Taniguchi et al. in neutral solution[18], the presence of the CoII(cyclam) complex electrocatalyzes the irreversible reduction of either nitrate or nitrite ions in $\mathrm{NaOH}$ solution. This behavior is exemplified by the appearance in the presence of nitrate of a large irreversible reduction wave, which is proportional to nitrate concentration, in the -1.3 to $-1.4 \mathrm{~V}$ region (see Figure 7). Very similar behavior is observed for the reduction of nitrite in the presence of the $\mathrm{Co}^{\mathrm{II}}$ (cyclam) complex. The 
peak currents for the reduction of either nitrate or nitrite are proportional to concentration over the range form $10^{-5}$ to $10^{-2} \mathrm{M}$.

The reduction of either nitrate or nitrite occurs in a potential region for all the cathode materials examined where there is no faradaic reaction for the CoIII(cyclam) complex in the absence of nitrate or nitrite. Tests indicated that the nitrate reduction current and potential are independent of $\mathrm{pH}$ at two different concentrations of the $\mathrm{Co}$ (II)(cyclam) complex, which is evidence that the trans- $\left(\mathrm{H}_{2} \mathrm{O}\right)_{2} \mathrm{Co}$ (cyclam) species is the thermodynamically stable product of the electrode reaction at -0.8 to $-0.9 \mathrm{~V}$. Thus it is this species that is present in the diffusion layer at potentials where the reduction of nitrate and nitrite takes place.

Figure 7. (A) Cyclic Voltammogram of $2.0 \times 10^{-3} \mathrm{M} \mathrm{Com}$ (cyclam) in $3.0 \mathrm{M} \mathrm{NaOH}$ at a Au(Hg) Disk Electrode [conditions: sweep rate $=20 \mathrm{mV} / \mathrm{sec}, \mathrm{S}=\mathbf{2} \mathrm{x}$ $10^{-6} \mathrm{~A}$, the dashed line is the current in the absence of the CoIII(cyclam) complex]

(B) Cyclic Voltammogram of the Solution from (A) with $3 \times 10^{-3} \mathrm{M}$ $\mathrm{NaNO}_{3}$ Added

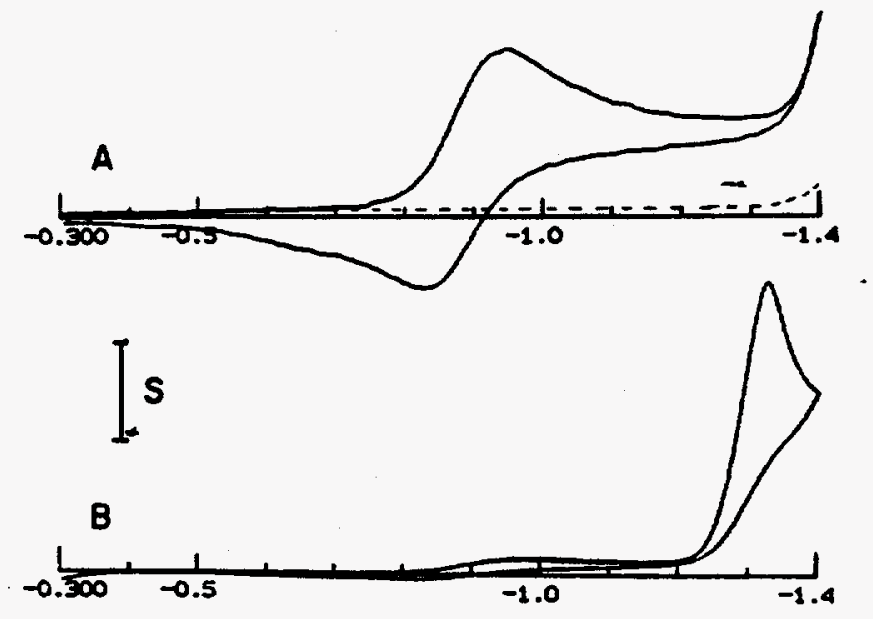

E / Volf vs S.C.E.

In the concentrated $\mathrm{NaOH}$ solutions the nitrate reduction peak currents exhibited a diffusion sweep rate dependence over the sweep rate range from 5 to $1000 \mathrm{mVs}^{-1}$ (i.e., $i_{p}=(\text { sweep rate })^{0.43}$. The peak potential, which was strongly dependent on the sweep rate, decreased ca. $60 \mathrm{mV} /$ decade increase in sweep rate and merged into the background process at faster sweep rates. Several experiments were carried out by using $\mathrm{D}_{2} \mathrm{O}$ as the solvent with added NaOD. At low sweep rates there is no significant difference between the cyclic voltammograms of the nitrate reduction process in $\mathrm{H}_{2} \mathrm{O}$ and in $\mathrm{D}_{2} \mathrm{O}$. The peak voltammograms obtained at the faster sweep rates in $\mathrm{D}_{2} \mathrm{O}$ were more drawn out and moved into the background process at lower sweep rates than in $\mathrm{H}_{2} \mathrm{O}$. 


\subsubsection{Controlled-Potential Electrolysis with CoII (cyclam) Complex}

Tables IV and $\mathrm{V}$ give results of controlled potential electrolysis of $\mathrm{NaNO}_{3}$ and $\mathrm{NaNO}_{2}$ solution $3 \mathrm{M} \mathrm{NaOH}$ in the presence and absence of the $\mathrm{Co}_{0}$ (cyclam) complex. All electrolyses were carried out at room temperature on solutions containing $4.0 \mathrm{mmol}$ of substrate and were terminated after 3 hours. Although all of the working electrodes had approximately the same area $\left(5 \mathrm{~cm}^{2}\right)$, comparisons between different electrode materials based on these data should be regarded as qualitative since cell conditions (electrode geometry, stirring rates, etc.) were not uniform, and the electrolyses were not carried out to the same percent completion.

With the exception of the zinc cathode, which participates in a nonelectrochemical reductive pathway, addition of the $\mathrm{Co}$ (cyclam) complex significantly increases the amount of nitrate or nitrite reduced at potentials positive of the background discharge process. Within the experimental errors of the analytical procedures, there is a reasonable correspondence between the amount of nitrate (or nitrite) reduced and the amount of ammonia, hydroxylamine, and nitrite produced. The current efficiencies given in the tables were calculated by assuming that dinitrogen was formed to satisfy the mass balance. The low current efficiencies observed in several of the electrolyses are presumably due to the coevolution of hydrogen at the negative potentials employed. Finally, the data suggest that a lead cathode is especially well suited for the reduction of nitrate and nitrite ions under these conditions. Accordingly, the combination of a lead cathode and a nickel anode for the oxidation of $\mathrm{OH}^{-}$to $\mathrm{O}_{2} / \mathrm{or} \mathrm{NH}_{2} \mathrm{OH}$ to $\mathrm{N}_{2}$ would seem to be a good choice for the electrochemical destruction of nitrate and nitrite.

\section{Table IV. Controlled Potential Electrolysis of $4.0 \mathrm{mmol}$ of $\mathrm{NaNO}_{3}$ in $40 \mathrm{~mL}$ of $3.0 \mathrm{M}$ $\mathrm{NaOH}$ Solution at Different Electrodes}

\begin{tabular}{|c|c|c|c|c|c|c|c|}
\hline \multirow{2}{*}{$\begin{array}{l}\text { cathode } \\
\text { material }\end{array}$} & \multirow{2}{*}{$\begin{array}{c}E_{\text {appł, }} \\
\text { v vs SCE }\end{array}$} & \multirow{2}{*}{$\begin{array}{c}{\left[\mathrm{Co}^{\mathrm{III}}\left({ }_{\text {(cyclam })}\right)\right]} \\
\mu \mathrm{M}\end{array}$} & \multirow{2}{*}{$\begin{array}{l}\text { mmol of } \\
\text { nitrate reduced }\end{array}$} & \multicolumn{3}{|c|}{ mmol of products } & \multirow{2}{*}{$\begin{array}{c}\text { current } \\
\text { efficiency. \% }\end{array}$} \\
\hline & & & & $\mathrm{NH}_{3}$ & $\mathrm{NO}_{2}^{-}$ & $\mathrm{NH}_{2} \mathrm{OH}$ & \\
\hline \multirow[t]{2}{*}{$\mathrm{Hg}$ pool } & -1.5 & 36 & 1.9 & 0.1 & 0.9 & 0.9 & 104 \\
\hline & & 0 & 0.4 & 0.1 & 0.2 & 0.2 & 39 \\
\hline \multirow[t]{2}{*}{ nickel } & -1.3 & 76 & 3.3 & 2.9 & $\mathrm{nd}^{\mathbf{a}}$ & $\mathrm{tr}^{b}$ & 76 \\
\hline & & 0 & 0.4 & 0.2 & 0.2 & nd & 95 \\
\hline \multirow[t]{2}{*}{ zinc } & -1.5 & 76 & 4.0 & 3.4 & nd & $\operatorname{tr}$ & 120 \\
\hline & & 0 & 4.0 & 2.5 & 1.2 & tr & 1.16 \\
\hline \multirow[t]{2}{*}{ lead } & -1.6 & 76 & 3.8 & 3.4 & nd & tr & 97 \\
\hline & & 0 & 3.0 & 2.3 & nd & nd & 84 \\
\hline \multirow[t]{2}{*}{ gold } & -1.6 & 38 & 2.6 & 0.8 & 1.1 & 0.7 & 40 \\
\hline & & 0 & 0.6 & nd & 0.3 & 0.3 & 47 \\
\hline \multirow[t]{2}{*}{ silver } & -1.5 & 76 & 1.4 & 1.1 & 0.1 & nd & 61 \\
\hline & & 0 & 0.5 & 0.1 & 0.2 & 0.2 & 32 \\
\hline
\end{tabular}

a Not detected. 'Trace detected. 
Table V. Controlled Potential Electrolysis of $4.0 \mathrm{mmol}$ of $\mathrm{NaNO}_{2}$ in $40 \mathrm{~mL}$ of $3.0 \mathrm{M}$ $\mathrm{NaOH}$ Solution at Different Electrodes

\begin{tabular}{|c|c|c|c|c|c|c|}
\hline \multirow[b]{2}{*}{$\begin{array}{l}\text { cathode } \\
\text { material }\end{array}$} & \multirow[b]{2}{*}{$\begin{array}{c}E_{\text {appl, }} \\
V \text { vs SCE }\end{array}$} & \multirow{2}{*}{$\begin{array}{c}{\left[\mathrm{Co}^{\mathrm{III}}(\text { cyclam })\right]} \\
\mu \mathrm{M}\end{array}$} & \multirow{2}{*}{$\begin{array}{c}\text { mmol of } \\
\text { nitrite reduced }\end{array}$} & \multicolumn{2}{|c|}{ mmol of products } & \multirow{2}{*}{$\begin{array}{c}\text { current } \\
\text { efficiency, \% }\end{array}$} \\
\hline & & & & $\mathrm{NH}_{3}$ & $\mathrm{NH}_{2} \mathrm{OH}$ & \\
\hline \multirow[t]{2}{*}{ Hg pool } & -1.5 & 38 & 3.0 & 0.2 & 2.2 & 81 \\
\hline & & 0 & 0.1 & $\mathrm{nd}^{a}$ & 0.1 & 69 \\
\hline \multirow[t]{2}{*}{ nickel } & -1.3 & 76 & 3.8 & 1.5 & $t^{b}$ & 89 \\
\hline & & 0 & 0.5 & 0.3 & nd & 83 \\
\hline \multirow[t]{2}{*}{ zinc } & -1.5 & 76 & 3.9 & 3.0 & 0.9 & 96 \\
\hline & & 0 & 3.5 & 2.6 & 0.7 & 93 \\
\hline lead & -1.6 & 76 & 3.6 & 2.7 & 0.8 & 100 \\
\hline \multirow{3}{*}{ gold } & & $\mathbf{0}$ & 0.2 & 0.1 & 0.1 & 21 \\
\hline & -1.6 & 38 & 3.1 & 1.9 & 1.2 & 77 \\
\hline & & 0 & 1.0 & 0.7 & 0.3 & 98 \\
\hline
\end{tabular}

- Not detected. 'Trace detected.

\subsubsection{Rotating Ring-Disk Experiments}

A striking feature of the cyclic voltammograms of the nitrate (or nitrite) containing solutions in the presence of the CoIII(cyclam) complex is the location of the nitrate reduction wave on the potential axis. The wave appears in a region where the $\mathrm{Co}$ (cyclam) species, e.g. $\mathrm{Co}^{\mathrm{II}}(\mathrm{cyclam})^{2+}$, seem to be electroinactive in the absence of nitrate or nitrite ions. This behavior suggests that there is an interaction of a $\mathrm{Co}^{\mathrm{I}}$ species with nitrate, i.e., either complexation of nitrate or rapid electron transfer to nitrate in the diffusion layer, which shifts the $\mathrm{Co} I / /$ redox couple to positive potentials out of the solvent discharge region.

To examine further whether the $\mathrm{Co}$ II(cyclam) complex undergoes a faradaic process in the presence of nitrate, several rotating ring-disk experiments were performed with a $\mathrm{Au}$ disk-Au ring electrode. Since a ring-disk electrode allows independent control of the sensing ring electrode, the detection of electroactive intermediates by fast-sweep cyclic voltammetry is less direct and often more difficult since it is necessary to monitor a faradaic current for the intermediate at some potential well removed from the potential where it is generated.

Experiments were conducted where the ring current at $-1.0 \mathrm{~V}$ was monitored as a function of the disk potential for different concentration of the $\mathrm{Co}^{\mathrm{II}}$ (cyclam) complex. As the disk potential is swept through the -0.8 to $-0.9 \mathrm{~V}$ region, the ring current for the $\mathrm{Co}$ IIIII reduction process decreases due to a shielding effect. This results because the flux of $\mathrm{Co}$ (III) to the ring is decreased by the disk electrode reaction(eq2). After correction for background current, the shielding factor was in agreement with theory.

In the absence of added nitrate, the ring current exhibits some fluctuation at very negative potentials (ca.-1.5V vs. SCE) where gas evolution was evident at the disk. Significantly, in the presence of $5 \times 10^{-3} \mathrm{M} \mathrm{NaNO}_{3}$, when the disk potential reaches the region where the reduction of nitrate takes place, ca. $-1.3 \mathrm{~V}$, the cathodic ring current increases for the lower catalyst concentration. This current change is in the opposite direction expected for a simple redox process for which the ring collection current would become more anodic when reduction products were formed at the disk. A possible explanation for this 
behavior is that the flux of $\mathrm{Co}^{\mathrm{III}}$ to the ring is increased by the catalytic process for the reduction of nitrate.

The magnitude of the ring current in the collection experiments was dependent on the concentration ratio of nitrate to cobalt. At a lower concentration of nitrate, or at a higher $\mathrm{Co}$ (cyclam) concentration, the collection current became more anodic when the disk potential was swept through the nitrate reduction process. This is consistent with detection of excess $\mathrm{Co}^{\mathrm{I}}$ that can reach the ring-disk experiments.

\subsubsection{Tests with Nafion ${ }^{\circledR}$ Coated Electrodes}

The cyclic voltammogram of the Co ${ }^{11}$ cyclam containing film in contact with $1 \mathrm{M} \mathrm{NaOH}$ and $10^{-4} \mathrm{M} \mathrm{NaNO}_{3}$ exhibits a quasi-reversible one-electron wave at a somewhat more negative potential than is seen for the Nafion ${ }^{\circledR}$ film electrode. Furthermore, in the Nafion ${ }^{\circledR}$ film the anodic segment of the wave is considerably drawn-out, and as the potential is cycled, the peak currents decrease due to loss of Co complex to the solution. However, the response for the complex in the film persists for many cycles (more than 20 ) and the electrode remains active for nitrate reduction. Electrodes could be easily reactivated simply by coating with a new aliquot of $\mathrm{Co}(\mathrm{III})$-cyclam containing Nafion ${ }^{\circledR}$.

Upon addition of low concentrations of nitrate to the $\mathrm{NaOH}$ solution, a nitrate dependent irreversible reduction wave appears at ca. $-1.35 \mathrm{~V}$. This wave is shifted by $200 \mathrm{mV}$ from the position of the nitrate reduction wave that appears just before the background reduction of water at an unmodified mercury electrode in $\mathrm{NaOH}$ solutions. The wave is proportional to nitrate concentration over the range from $10^{-4}$ to $10^{-2} \mathrm{M}$. At concentrations greater than $10^{-3} \mathrm{M}$, the peak potential for this wave is strongly dependent on nitrate, shifting to negative potential at $60 \mathrm{mV}$ per decade change in the nitrate concentration.

The Co-cyclam containing Nafion ${ }^{\circledR}$ modified electrodes responded to nitrite ions in a manner similar to nitrate. Cyclic voltammograms of $\mathrm{NaNO}_{2}$ in $1 \mathrm{M} \mathrm{NaOH}$ obtained with the modified electrode show an irreversible nitrite reduction wave at ca. -1.3. V. As with nitrate solutions, this wave is not present in the absence of the Co(cyclam) complex. For both the nitrate and nitrite reductions, the peak current for the electrocatalytic process at sweep rate of $20 \mathrm{mV} / \mathrm{s}$ was proportional to the nitrate or nitrite concentration over the range of $10^{-4}$ to $10^{-2} \mathrm{M}$ for a given modified electrode. For the same modified surface, the current response to nitrate and nitrite was in the approximate ratio of $3: 2$, which is consistent with a diffusion controlled reduction to hydroxylamine, six and four-electron reduction, respectively.

A notable feature of these voltammograms of nitrite solutions is the appearance of an anodic wave at ca. $-0.37 \mathrm{~V}$ that appears to be due to oxidation of a nitrite reduction product. This wave is usually present in the cyclic voltammograms of nitrate as well, but it is larger and more evident for nitrite. The $\mathrm{Co}$ (III/II) wave in the cyclic voltammograms is not influenced significantly by the addition of either nitrate or nitrite to the solution.

An advantage of immobilizing the Co-cyclam catalyst in a Nafion ${ }^{\circledR}$ film electrode is that negatively charged interfering species might be excluded from the reaction site. An example is the chromate dianion which can oxidize intermediates and products of the nitrate reduction process, thereby thwarting the electrochemical destruction of nitrate. Accordingly, the effect of chromate on the cyclic voltammetry of nitrate at the Co-cyclam Nafion ${ }^{\circledR}$ electrode was examined. 
At low chromate concentration, less than $0.02 \mathrm{M}$, the cyclic voltammograms of nitrate are not markedly influenced by the addition of $\mathrm{CrO}_{4}{ }^{2-}$. At higher concentrations, however, more complex behavior is seen suggesting that chromate ion is not excluded from the modified electrode interface. In the absence of nitrate or at low nitrate concentration, some electrocatalysis of the chromate reduction is indicated by the increased cathodic peak current for the $\mathrm{Co}$ (III) reduction and the $(\mathrm{ip})^{\mathrm{c}} /(\mathrm{i} p)^{\mathrm{a}}$ peak current ratio being greater than unity. Upon addition of nitrate, the usual nitrate reduction and hydroxylamine oxidation waves appear. At high nitrate concentration, the Co(III/II) waves become dependent on the nitrate concentration. This result suggests that a reduced form of chromate generated in the diffusion layer at $-0.8 \mathrm{~V}$ by reaction with $\mathrm{Co}$ (II) can reduce nitrate ion. Significantly, the votammmograms indicate that although the redox chemistry is complex, nitrate is still reduced under voltammetric conditions, although the increased current in the $-1.4 \mathrm{~V}$ region must be due in part to the reduction of chromate.

\section{Savannah River Technology Center Tests [19-23]}

Undivided single cell reactors similar to the IHC cells were constructed at SRTC. Tests were carried out using these reactors to (1) quantify the effect of chromate on the current efficiency, (2) investigate the reduction of ruthenium and technetium, and (3) demonstrate nitrate and nitrite destruction in actual SRS waste. Subsequent tests evaluated nitrate destruction in a laboratory-scale flow cell reactor.

\subsection{Effect of Chromate}

A series of constant current $\left(1080 \mathrm{~A} / \mathrm{m}^{2}\right)$ electrolyses were carried out by adding sodium chromate to a decontaminated salt solution simulant prepared without chromate (see Table I). The electrolyses were carried out in the undivided SRTC-1 reactor equipped with nickel electrodes for both the cathode and anode. The electrode spacing in the undivided cell was $5.08 \mathrm{~cm}$. Each test was carried out until no further change in the hydroxide concentration was detected.

Figure 8 shows a plot of the percent nitrate and nitrite removed from solution and the calculated current efficiency (\%) versus the concentration of chromate (ppm). As the concentration increased the current efficiency decreased. With no chromate present, the current efficiency was $72 \%$, but rapidly dropped as the chromate concentration increased. At a chromate concentration of $318 \mathrm{ppm}$, the current efficiency had dropped to less than $10 \%$ and only about $20 \%$ of the nitrate and nitrite had been destroyed when the test was stopped. 
Figure 8. Effect of Chromate Concentration in the Reduction of Nitrate and Nitrite in an Undivided Batch Cell

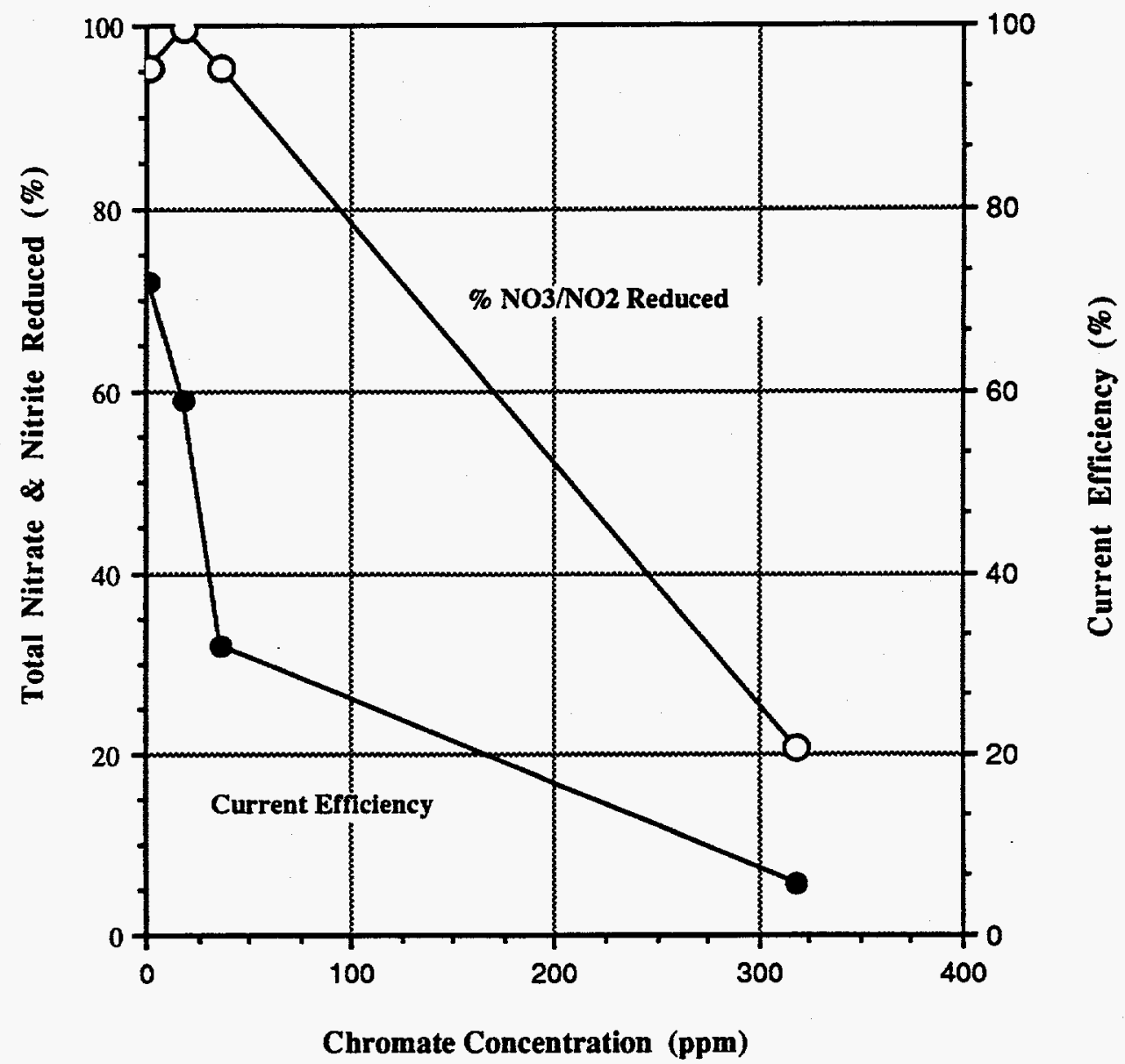

\subsection{Removal of Ruthenium and Technetium}

Constant current electrolyses were carried out in an undivided, single-cell reactor in the same manner as previously described for the tests determining the effect of chromate. For the ruthenium removal tests, sodium tetranitronitrosylruthenate(II), $\mathrm{Na}_{2}\left[\mathrm{Ru}(\mathrm{NO})\left(\mathrm{NO}_{2}\right)_{4}(\mathrm{OH})\right]$, was used as the ruthenium compound. This compound was selected as the model compound for the class of ruthenium compounds that have been identified in SRS HLW. For the tests investigating the removal of technetium, ${ }^{99} \mathrm{Tc}$, as $\mathrm{NaTcO}_{4}$ in $0.1 \mathrm{M} \mathrm{NaOH}$, was added to the simulant.

Figure 9 shows a plot of the nitrate concentration and the $\mathrm{Ru}$ decontamination factor versus electrolysis time. The decontamination factor is the ratio of the initial ruthenium concentration to that at the time when the sample is taken. During the first 20 hours of the test, approximately $60 \%$ of the nitrate and $85 \%$ of the ruthenium are removed. Over the next two hours, another $13 \%$ of the ruthenium is removed bringing the total 
ruthenium removed to $98 \%$. At this point in time, about $80 \%$ of the nitrate has been destroyed. It is believed that ruthenium is continuing to be removed from solution, but this could not be verified in this test since the detection limit for ruthenium had been reached at this point.

After completion of the test, the cell was disassembled and the cathode inspected. A black solid, identified as elemental ruthenium, had been deposited on the cathode. The deposit adhered strongly to the cathode. Washing with detergent and water did not remove the deposit. Soaking the electrode in $2 \mathrm{M}$ nitric acid at ambient laboratory temperature also did not remove the deposit.

Figure 9. Nitrate Concentration and Ruthenium Decontamination Factor Versus Electrolysis Time

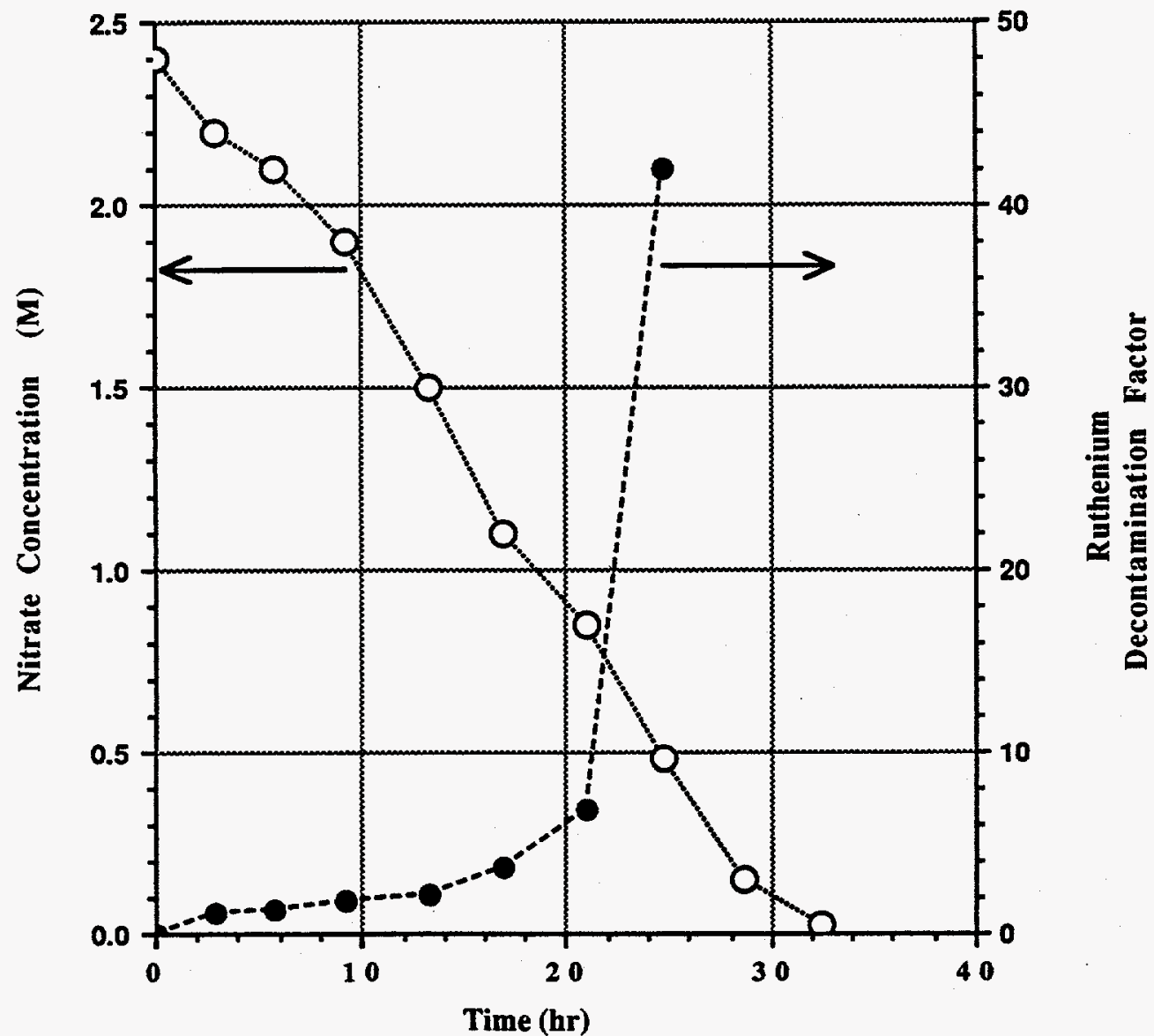


Figure 10 shows a plot of the nitrate concentration and technetium decontamination factor versus the electrolysis time. During the first 20 hours of electrolysis, approximately $75 \%$ of the nitrate had been destroyed. At this point, the removal of technetium had plateaued at about $95 \%$, where it remained for 6-8 hours before increasing. At the conclusion of the test, $99.98 \%$ of the technetium had been removed from solution.

Figure 10. Nitrate Concentration and Technetium Decontamination Factor Versus Electrolysis Time

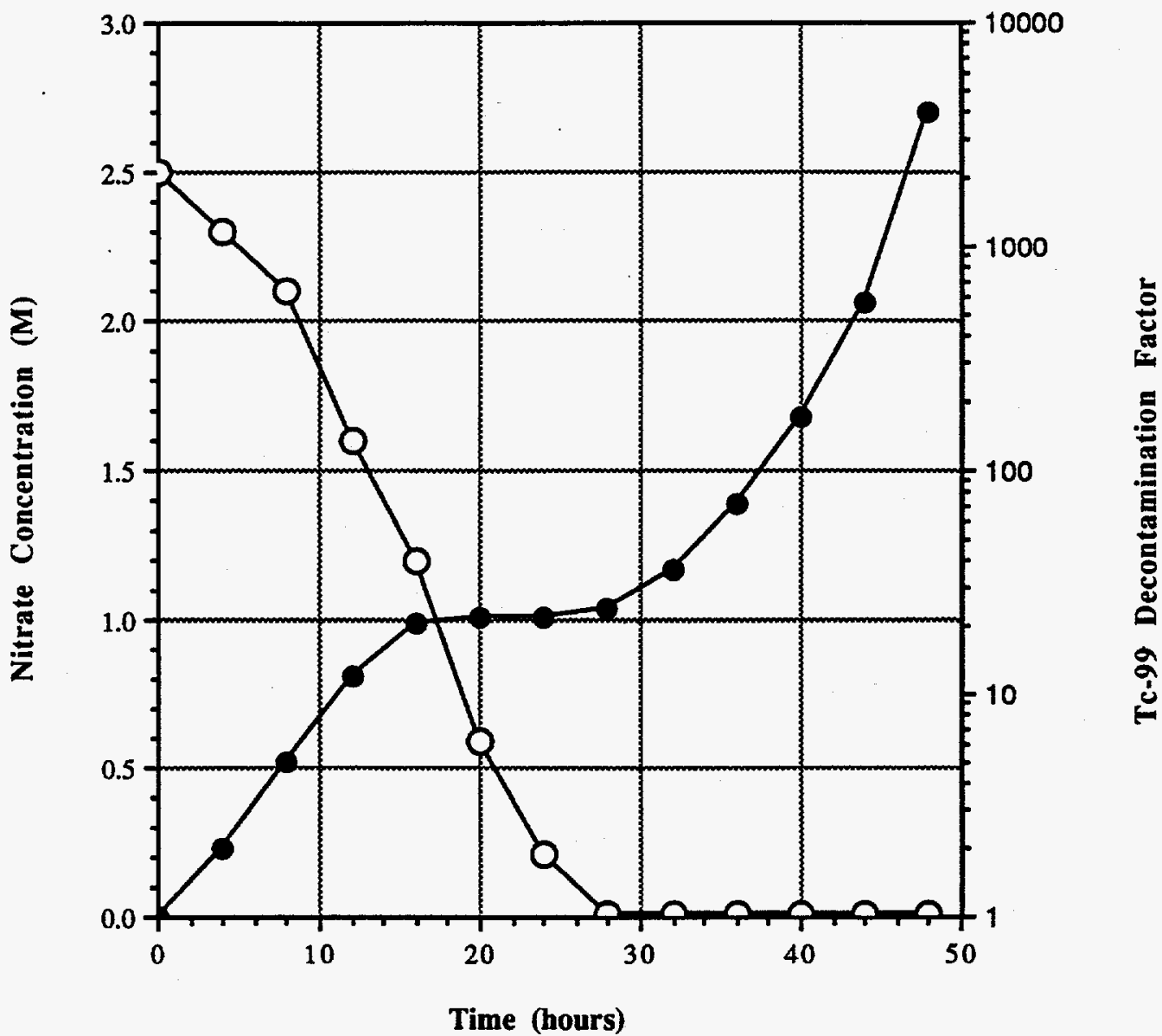

In contrast to the ruthenium deposit on the cathode, the technetium deposit is very easily removed. Reversal of the cell potential followed by electrolysis for a brief period of time oxidized the technetium oxide to pertechnetate which rapidly dissolved. Alternatively, turning off the power supply and soaking the electrode in the strongly alkaline solution resulted in the removal of the deposit. Greater than $95 \%$ of the deposited technetium was removed by either method. 


\subsection{Tests with Actual SRS Waste}

Two tests were carried out with actual SRS waste in the undivided single-cell using nickel electrodes. The waste used in these tests came from Tank $50 \mathrm{H}$, which contained the decontaminated salt solution produced from the full-scale demonstration of the InTank Precipitation process carried out in 1983. The composition of the solution is provided in Table VI.

In the first test, the pair of nickel electrodes used in the ruthenium tests, were utilized. The cathode still had the black ruthenium deposit. In the second test, a pair of virgin nickel electrodes were used. In both tests, the electrolysis was carried out for 48 hours at a current density of $1080 \mathrm{~A} / \mathrm{m}^{2}$. Samples of the solution were periodically taken over the 48 hour test period. A plot of the total nitrate and nitrite concentration versus the electrolysis time is presented in Figure 11 for each test.

Table VI. Composition of Tank 50H Waste Used in Electrolysis Tests

$\begin{array}{lc}\text { Species } & \text { Concentration } \\ \mathrm{NO}_{3}{ }^{-} & 2.7 \mathrm{M} \\ \mathrm{NO}_{2}{ }^{-} & 0.25 \mathrm{M} \\ \mathrm{OH}^{-} & 0.95 \mathrm{M} \\ \mathrm{CO}_{3}{ }^{2-} & 0.19 \mathrm{M} \\ \mathrm{Al}(\mathrm{OH})_{4}{ }^{-} & 0.24 \mathrm{M} \\ \mathrm{SO}_{4}{ }^{2-} & 0.13 \mathrm{M} \\ \mathrm{Na}^{+} & 5.5 \mathrm{M} \\ \mathrm{P} & 130 \mathrm{mg} / \mathrm{L} \\ \mathrm{Zn} & 32 \mathrm{mg} / \mathrm{L} \\ \mathrm{Cr} & 7.4 \mathrm{mg} / \mathrm{L} \\ { }^{137} \mathrm{Cs} & 4.0 \mu \mathrm{Ci} / \mathrm{mL} \\ { }^{134} \mathrm{Cs} & 0.0082 \mu \mathrm{Ci} / \mathrm{mL} \\ { }^{106} \mathrm{Ru} & 0.89 \mu \mathrm{Ci} / \mathrm{mL} \\ { }^{99} \mathrm{Tc} & 0.017 \mu \mathrm{Ci} / \mathrm{mL} \\ { }^{90} \mathrm{Sr} & 4.5 \mathrm{E}-5 \mu \mathrm{Ci} / \mathrm{mL}\end{array}$

Faster and more complete removal of the nitrate and nitrite was observed in the test with the virgin set of nickel electrodes. Apparently, the ruthenium deposit inhibited the reduction of nitrate and nitrite. Overall, $79 \%$ of the nitrate and nitrite were removed in the test having the Ru-coated cathode and $91 \%$ of the nitrate and nitrite in the uncoated cathode test. In both tests, the reduction of nitrate and nitrite was completed after about 30 hours.

${ }^{106} \mathrm{Ru}$ and ${ }^{99} \mathrm{Tc}$ were also removed during the test. The percentage of each that was removed is provided in Table VII. The removal of ruthenium, but not technetium is enhanced by the presence of a ruthenium deposit on the cathode. However, the ruthenium coating on the cathode decreases the removal of nitrate and nitrite. 
Figure 11. Plot of Total Nitrate and Nitrite Concentration in Actual Waste Versus Time

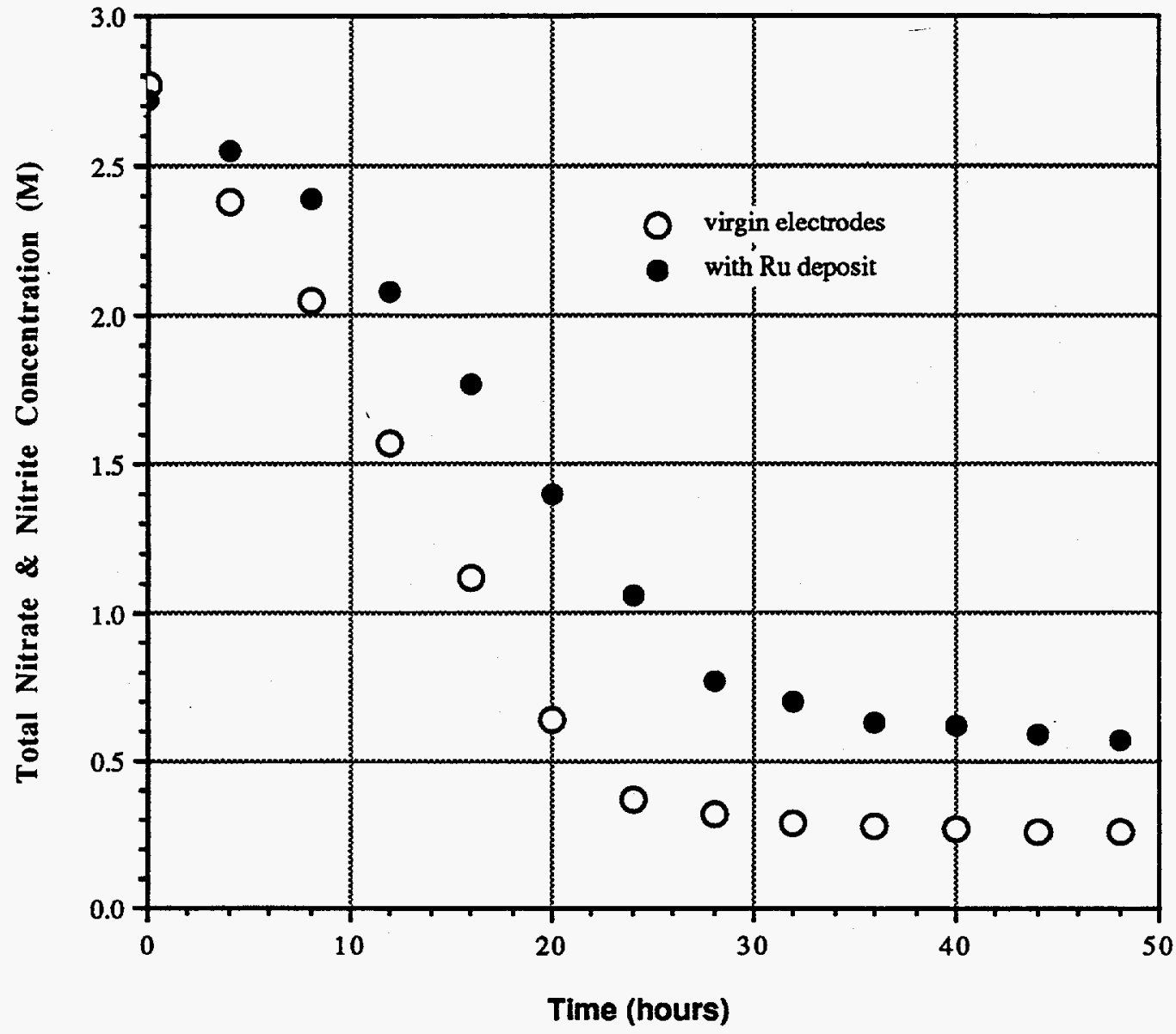

Table VII. Percentage of ${ }^{106} \mathrm{Ru}$ and ${ }^{99} \mathrm{Tc}$ Removed During Electrolysis of SRS Actual Waste

\section{\% Removed}

\section{Cathode}

Ru-coated

uncoated
${ }^{106} \mathrm{Ru}$

74

31
${ }^{99} \mathrm{Tc}$

58

56 


\subsection{Microflow Cell Tests}

The next series of tests was carried out to demonstrate the destruction of nitrate and nitrite in a parallel-plate flow reactor. A small electrochemical reactor referred to as the Microflow reactor manufactured by ElectroCell AB (Sweden) was utilized for the initial evaluation. This reactor has a working area of $0.001 \mathrm{~m}^{2}$ and electrolyte volume per cell compartment of approximately $5 \mathrm{~mL}$.

Using the decontaminated salt solution simulant, nitrate and nitrite were destroyed in flow cell as shown in Figure 12. In this test, the cell was arranged in an undivided cell configuration with a lead cathode and nickel anode. The current density was held constant throughout the experiment at $1000 \mathrm{~A} / \mathrm{m}^{2}$. The increase in the hydroxide concentration during the test is consistent with the decrease in the nitrate and nitrite concentrations. Note that the nitrite concentration increases slightly during the initial stages of the run, and then slowly decreases during the latter stages.

In contrast to the behavior observed in the unstirred rectangular batch cells with $\mathrm{Ni}$ electrodes, high chromate concentrations did not inhibit the reduction of nitrate and nitrite in the Microflow cell. Addition of between $0.00033(320 \mathrm{ppm})$ and $0.091 \mathrm{M}(11,000$ $\mathrm{ppm}$ ) chromate resulted in a small decrease in the rate of nitrate and nitrite removal using a flow cell equipped with a $\mathrm{Pb}$ cathode and $\mathrm{Ni}$ anode. However, greater than $95 \%$ of the nitrate and nitrite could be destroyed even at the extremely high chromate concentration.

The effects of flowrate and electrode spacing in the Microflow cell were also investigated. The electrode spacing was observed to have a larger effect than the flowrate on the reaction rate. Decreasing the distance between the electrodes increased the reaction rate by $13 \%$ (see Table VIII). 
Figure 12. Changes in Nitrate, Nitrite and Hydroxide Concentrations with Time During Electrolysis in the Micro Flow Electrochemical Reactor

Conditions: Undivided cell with $\mathrm{Pb}$ cathode and Ni anode, electrode spacing $=5.75 \mathrm{~mm}$, current density $=1000 \mathrm{amp} / \mathrm{m} 2$, flowrate $=10 \mathrm{~mL} / \mathrm{min}$.

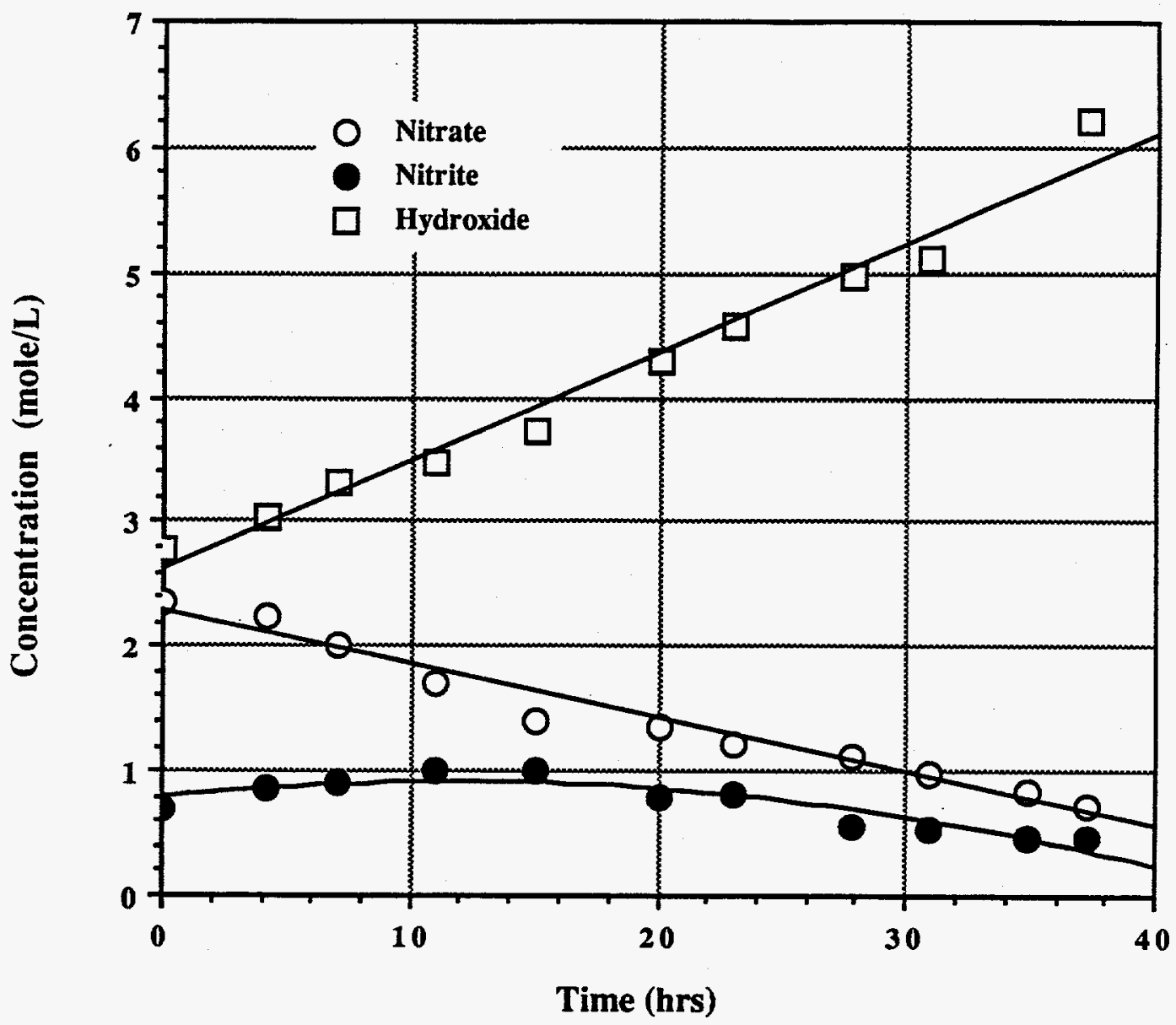

Table VIII. Effect of Electrode Spacing and Flowrate on Rate of Nitrate and Nitrite Destruction in a Microflow Cell ${ }^{\mathrm{a}}$

\begin{tabular}{ccc} 
Electrode Spacing $(\mathrm{mm})$ & Elowrate $(\mathrm{mL} / \mathrm{min})$ & $-\mathrm{d}\left[\mathrm{NO} \mathrm{x}_{\mathrm{x}} / \mathrm{dt}(\mathrm{mole} / \mathrm{L} / \mathrm{hr})^{\mathrm{b}}\right.$ \\
\hline 5.75 & 10.0 & 0.0649 \\
5.75 & 31.6 & 0.0643 \\
3.15 & 10.0 & 0.0768 \\
3.15 & 31.6 & 0.0692
\end{tabular}

a $\mathrm{Pb}$ cathode and $\mathrm{Ni}$ anode.

b $-d\left[N_{x}\right] / d t$ equals the slope of the linear fit of the sum of the nitrate and nitrite concentration data as a function of time. 
The addition of mercury as mercuric nitrate $(0.0010 \mathrm{M})$ and sodium tetraphenylborate, NaTPB $(0.0026 \mathrm{M})$, to the simulated salt solution resulted in a decrease in the rate of nitrate and nitrite reaction by $38 \%$. Interestingly, the rate of formation of hydroxide was similar to that for solutions without mercury or NaTPB. It is believed that both mercury and NaTPB are electrochemically active and are competing with nitrate and nitrite for current resulting in slower nitrate and nitrite reduction rates.

In laboratory tests at the University of Tennessee, cobalt cyclam complexes were found to catalyze the electrochemical reduction of nitrate and nitrite in alkaline salt solutions (see Section 3.3.2.). Two tests in which varying amounts of the cobalt cyclam complex were added to the salt solution were carried out in the Microflow reactor. At a cobalt cyclam concentration of $7.6 \times 10^{-5} \mathrm{M}$, there was no increase in the rate of nitrate and nitrite removal in the flow cell equipped with a $\mathrm{Pb}$ cathode and $\mathrm{Ni}$ anode. However, at a concentration of $5.9 \times 10^{-4} \mathrm{M}$, the reaction rate increased by $62 \%$.

A series of tests were carried out in the Microflow cell to determine the effect of temperature and electrode combinations on the cell voltage and current density. Combinations tested in an undivided cell configuration included (cathode/anode): (1) $\mathrm{Ni} / \mathrm{N}$, (2) $\mathrm{Pb} / \mathrm{Ni}$, (3) $\mathrm{Ni} / \mathrm{DSA}-\mathrm{O}_{2}$, and (4) $\mathrm{Ni} / \mathrm{DSA}-\mathrm{Cl}_{2}$. The latter two anode materials are coated electrodes that were developed for fuel-cell and chlor-alkali applications. Plots of the cell potential versus current density for each combination at $40^{\circ} \mathrm{C}$ and $90^{\circ} \mathrm{C}$ are shown in Figure 13.

Increasing the temperature from $40^{\circ} \mathrm{C}$ to $90^{\circ} \mathrm{C}$ resulted in a significant decrease in the cell voltage for a given current density for all of the combinations. The lead, nickel, and DSA- $\mathrm{O}_{2}$ electrodes were stable over the tested range of cell voltages and current densities. At $90^{\circ} \mathrm{C}$, the DSA-Cl ${ }_{2}$ electrode failed after reaching a voltage of $4.2 \mathrm{~V}$ and current density of $1900 \mathrm{~A} / \mathrm{m}^{2}$. Nickel generally exhibited a lower cell voltage than lead over the range of current densities at both temperatures suggesting that the use of nickel may reduce the overall power consumption at a given current density. 
Figure 13. Cell Potential Versus Current Density for Different Electrode Combinations at $40^{\circ} \mathrm{C}$ and $90^{\circ} \mathrm{C}$.

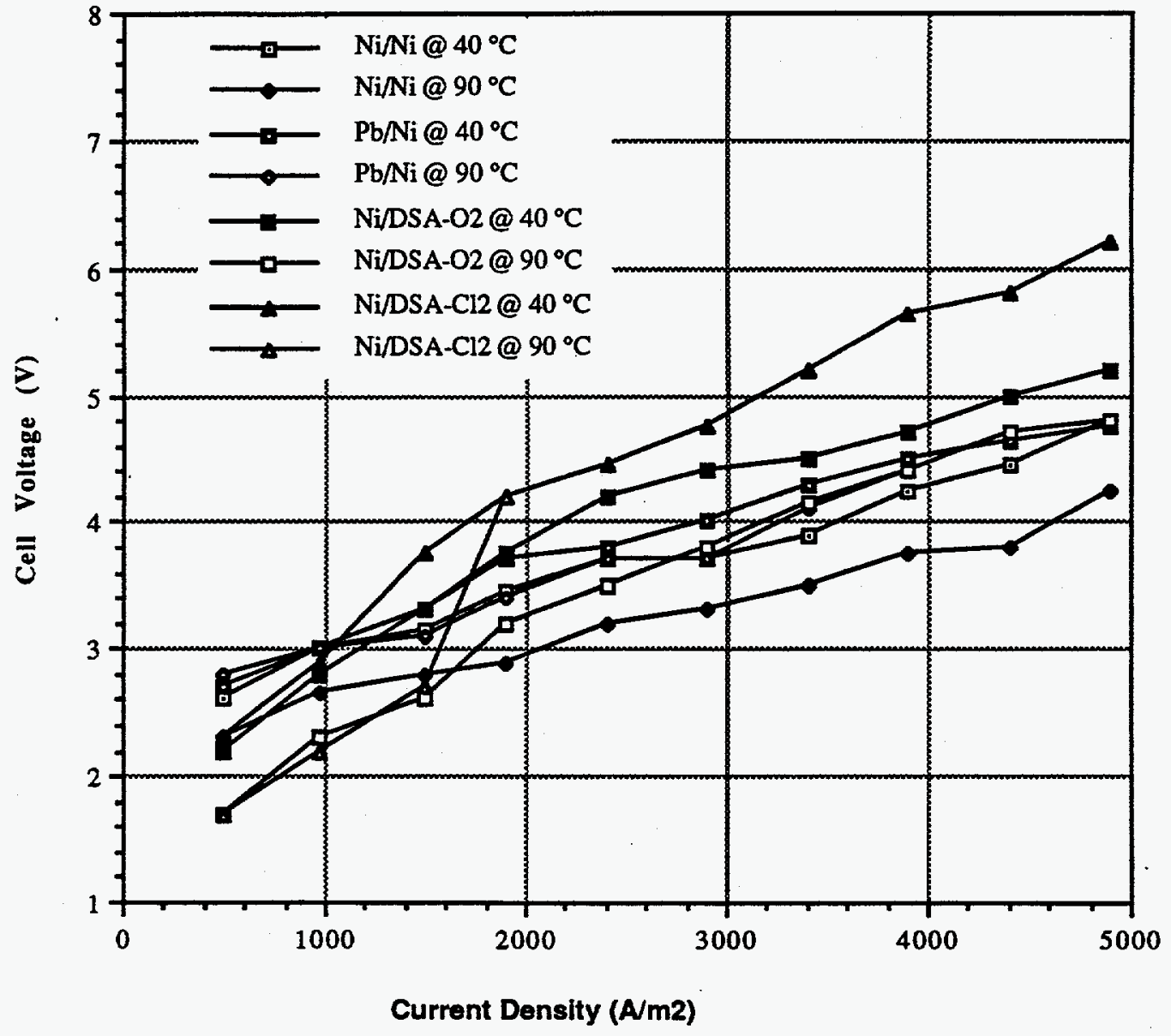

5. Evaluation of Electrode Materials and Cell Configuration at the Electrosynthesis Company $[24,25]$

5.1 Cathode Materials for Nitrate Reduction

5.1.1. Divided Glass Cell Cathode Screening With Simplified Simulant

Potential cathode materials were screened by performing galvanostatic electrolyses in a divided glass cell. A simplified mixture containing only $\mathrm{NaNO}_{3}, \mathrm{NaNO}_{2}$, and $\mathrm{NaOH}$ was used so that possible interferences from other species present in the complete mix could be eliminated. $\mathrm{N}_{2}, \mathrm{~N}_{2} \mathrm{O}$, and $\mathrm{NH}_{3}$ were the only products identified.

Table IX gives destruction efficiencies (100\% destruction efficiency corresponds to the formation of $\mathrm{NO}_{2}{ }^{-}$and $\mathrm{N}_{2}$ at $100 \%$ current efficiency) for $\mathrm{NO}_{2}{ }^{-}-\mathrm{NO}_{3}{ }^{-}$reduction and off- 
gas composition at the various cathode materials tested. Destruction efficiencies $\left(\mathrm{Q}_{\mathrm{T}} / \mathrm{Q}\right)$ were calculated from the charge, $Q$ (coulombs), assuming that nitrite is reduced to nitrogen, a three electron process, and nitrate is reduced to nitrite and then to nitrogen, a five electron process. The following equation was used:

$$
\mathrm{Q}_{\mathrm{T}}=\left(\left(\text { Change moles } \mathrm{NO}_{2}-* 3\right)+\left(\text { Change moles } \mathrm{NO}_{3}^{-* 5}\right)\right) * 96500
$$

The destruction efficiency gives the efficiency for nitrate and nitrite removal regardless of which gaseous reduction product is formed and provides a basis for comparing cathode materials and the effect of other experimental parameters. The results are reported at about 60,000 coulombs, which corresponds to approximately $3 / 4$ of the charge needed to completely reduce all of the $\mathrm{NO}_{2}^{-}$and $\mathrm{NO}_{3}{ }^{-}$in solution to nitrogen at $100 \%$ destruction efficiency. The off gas composition given in Table 1 gives area percentages of product gases since a standard gas mix was not available for the glass cell studies and thus component response factors could not be determined. Hydrogen was not analyzed and, therefore, not included in the off-gas composition.

Table IX. Nitrate/Nitrite Destruction in Glass Cell at Various Electrode Materials

\section{Destruction Efficiency}

Electrode

Lead

Cadmium

Lead Alloy

316 SS

Nickel

Copper

Porous Nickel

ATJ Graphite

Metcote ES-6
(\%)

100

99

92

83

81

79

78

76

64

Off-Gas Concentration \% Nitrogen \% Nitrous Oxide \% Ammonia

75

69

67

55

45

37

63

43

75
24

3

32

32

38

57

35

54

0
1

28

2

12

17

6

2

4

25

Conditions: $\quad$ Catholyte $=1.95 \mathrm{M} \mathrm{NaNO}_{3}, 0.60 \mathrm{M} \mathrm{NaNO} \mathrm{N}_{2}, 1.33 \mathrm{M} \mathrm{NaOH}(70 \mathrm{~mL})$ Anolyte $=1.0 \mathrm{M} \mathrm{H}_{2} \mathrm{SO}_{4}(150 \mathrm{~mL})$

Pt Anode, Nafion ${ }^{\circledR}$ Type 417 membrane separator

Electrode surface area $=0.0005 \mathrm{~m}^{2}$

Current Density $=1400 \mathrm{~A} / \mathrm{m} 2$, Ambient temperature

Results reported at 60,000 coulombs

The efficiencies for $\mathrm{NO}_{2}{ }^{-}$and $\mathrm{NO}_{3}{ }^{-}$destruction correlate with the hydrogen overpotentials of the metals tested with the most efficient reactions seen at lead and its alloys and cadmium. This is in agreement with literature reports indicating that better current efficiencies could be obtained with lead as opposed to nickel. This is to be expected 
since the competing reaction to nitrate reduction is hydrogen evolution. Lead also produced the lowest level of ammonia. Metcote ES-6 (ICI proprietary coating) has the lowest hydrogen overpotential and gives the poorest destruction efficiency and the largest amount of ammonia production. The other materials tested are intermediate in terms of destruction efficiency and ammonia production. A zinc cathode corroded severely.

\subsubsection{Divided Flow Cell Cathode Screening With Complete Simulant}

The MP flow cell (ElectroCell AB, Sweden) was used for flow cell cathode screening with the complete decontaminated salt solution composition (see Table I). The cell was operated in a divided configuration so as to remove possible interferences such as nitrite oxidation at the anode. Figure 14 shows the destruction of nitrite and nitrate in the complete simulant at lead and nickel cathodes. With a lead cathode, nitrite builds up in solution while nitrate levels decline and then nitrite levels decline. This suggest that the conversion of nitrite to gaseous reduction products is the slow step in the reaction mechanism. At nickel, the pronounced increase in nitrite levels is not observed, instead, both nitrite and nitrate decrease throughout the experiment. This suggests that the mechanism for nitrate reduction at nickel is the conversion of nitrate to nitrite.

\section{Figure 14. Effect of Cathode Material on Nitrate and Nitrite Removal in Divided Flow Cell Reactor}

Test Conditions: MP flow cell equipped with Nafion ${ }^{\circledR}$ type 417 membrane, Pt anode, $5000 \mathrm{~A} / \mathrm{m}^{2}$ current density, $70^{\circ} \mathrm{C}, 3 \mathrm{M}$ sulfuric acid anolyte, flowrate $=1.0 \mathrm{gpm}$

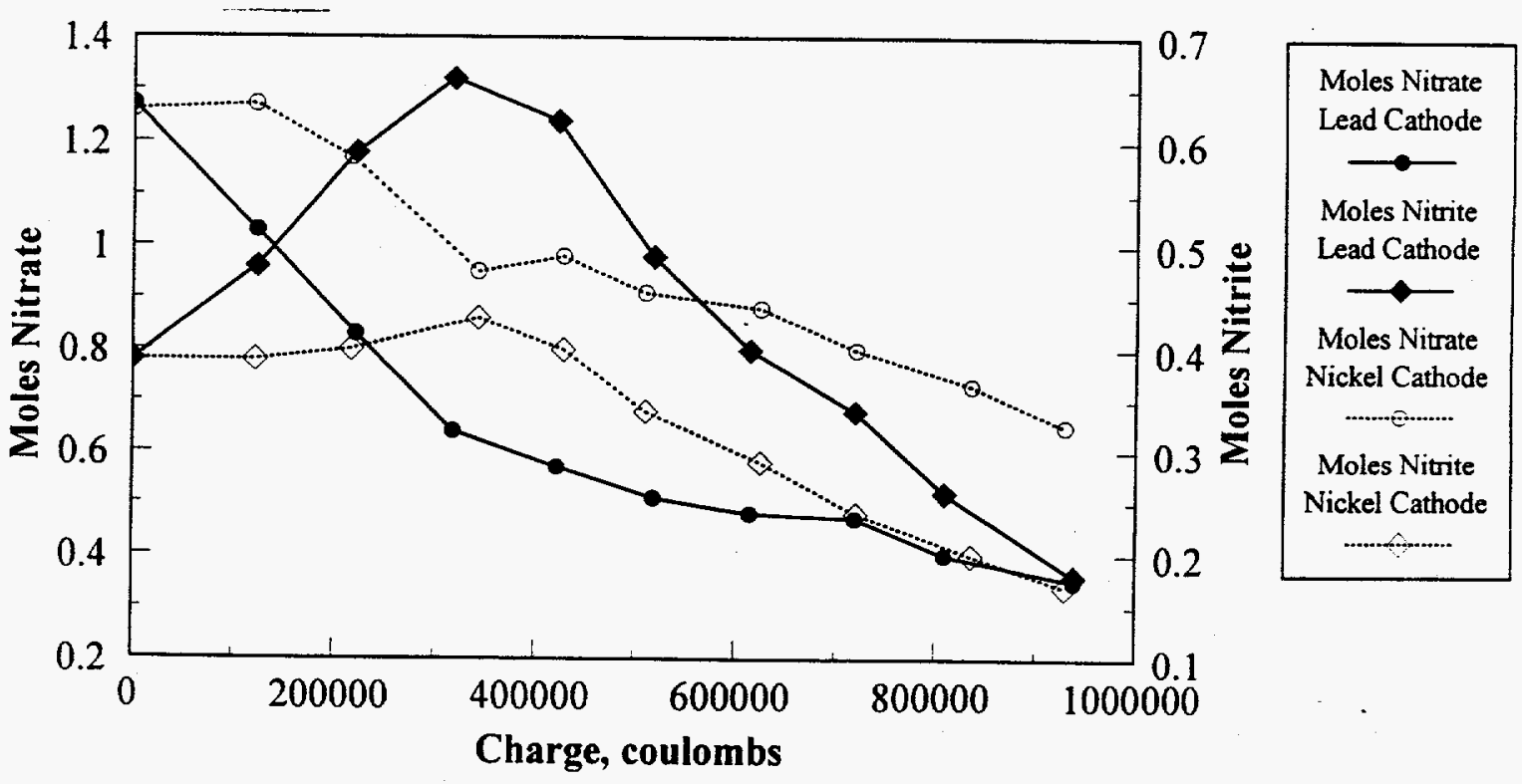


A standard gas mixture was used during the flow cell experiments so that response factors and actual volumetric percentages could be calculated for the product gases. Figure 15 gives the off gas composition at lead and nickel cathodes when the complete mix is used. At both cathodes, nitrogen and nitrous oxide are the major nitrogen containing products early in the experiment with ammonia becoming the dominant gas product in the second half of the experiment. Lead gives greater amounts of the nitrogen containing reduction products than does nickel, as is expected since more destruction of nitrate and nitrite and better destruction efficiencies were observed at the lead cathode.

\section{Figure 15. Off Gas Compositions at Lead and Nickel Cathodes in Divided Flow Cell Reactor}

Test Conditions: MP flow cell equipped with Nafion ${ }^{\circledR}$ type 417 membrane, Pt anode, $5000 \mathrm{~A} / \mathrm{m}^{2}$ current density, $70^{\circ} \mathrm{C}, 3 \mathrm{M}$ sulfuric acid anolyte, flowrate $=1.0 \mathrm{gpm}$
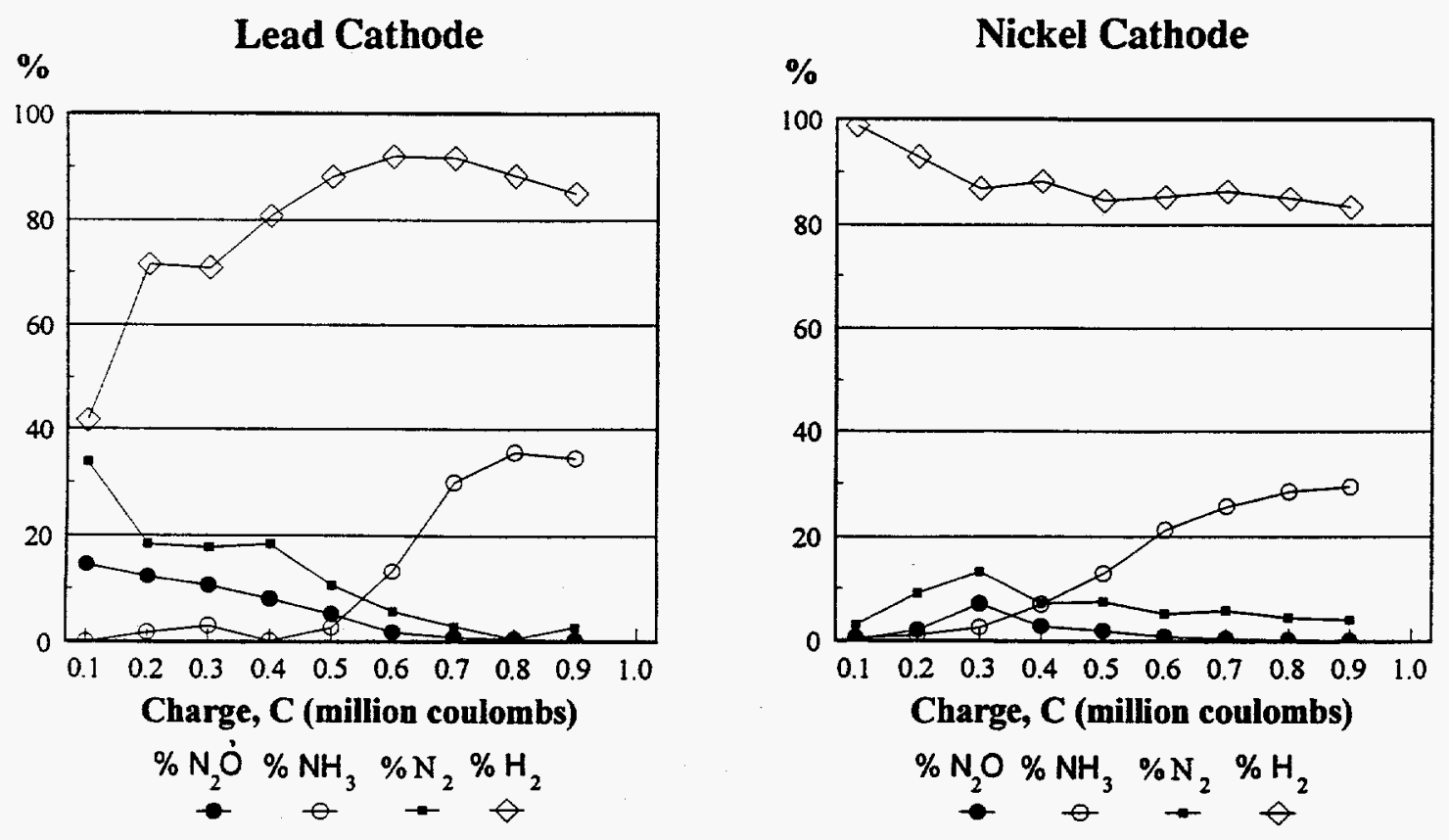

Figure 16 shows cumulative destruction efficiencies for all cathode materials tested in the divided flow cell with the complete mix. Lead achieves the most efficient destruction of nitrite and nitrate. The cumulative destruction efficiency at lead starts at about $70 \%$ and drops to $50 \%$ as nitrite and nitrate are depleted. Destruction efficiencies at lead with the simplified mix in the glass cell experiments approached $100 \%$. Cumulative destruction efficiencies for nitrite and nitrate removal at nickel and graphite are also worse in the complete mix than in the simplified mix used in the glass cell experiments. The remaining cathode materials tested, copper, 316 stainless steel, and platinum, achieved little nitrate destruction as evidenced by the poor destruction efficiencies. These materials also gave only trace amounts of nitrogen containing reduction products and large amounts of hydrogen. This is in contrast with the results seen in the glass cell (Table IX) where stainless steel and copper performed reasonably well. Clearly, other components in the complete mix interfere with the reduction process to a lesser or greater extent at all cathode materials tested. 
Figure 16. Comparison of Cathode Materials for the Destruction of Nitrate/Nitrite in a Divided Flow Cell Reactor

Test Conditions: MP flow cell equipped with Nafion ${ }^{\circledR}$ type 417 membrane, Pt or DSA-O 2 anode, $5000 \mathrm{~A} / \mathrm{m}^{2}$ current density, $70^{\circ} \mathrm{C}, 3 \mathrm{M}$ sulfuric acid anolyte, flowrate $=1.0 \mathrm{gpm}$

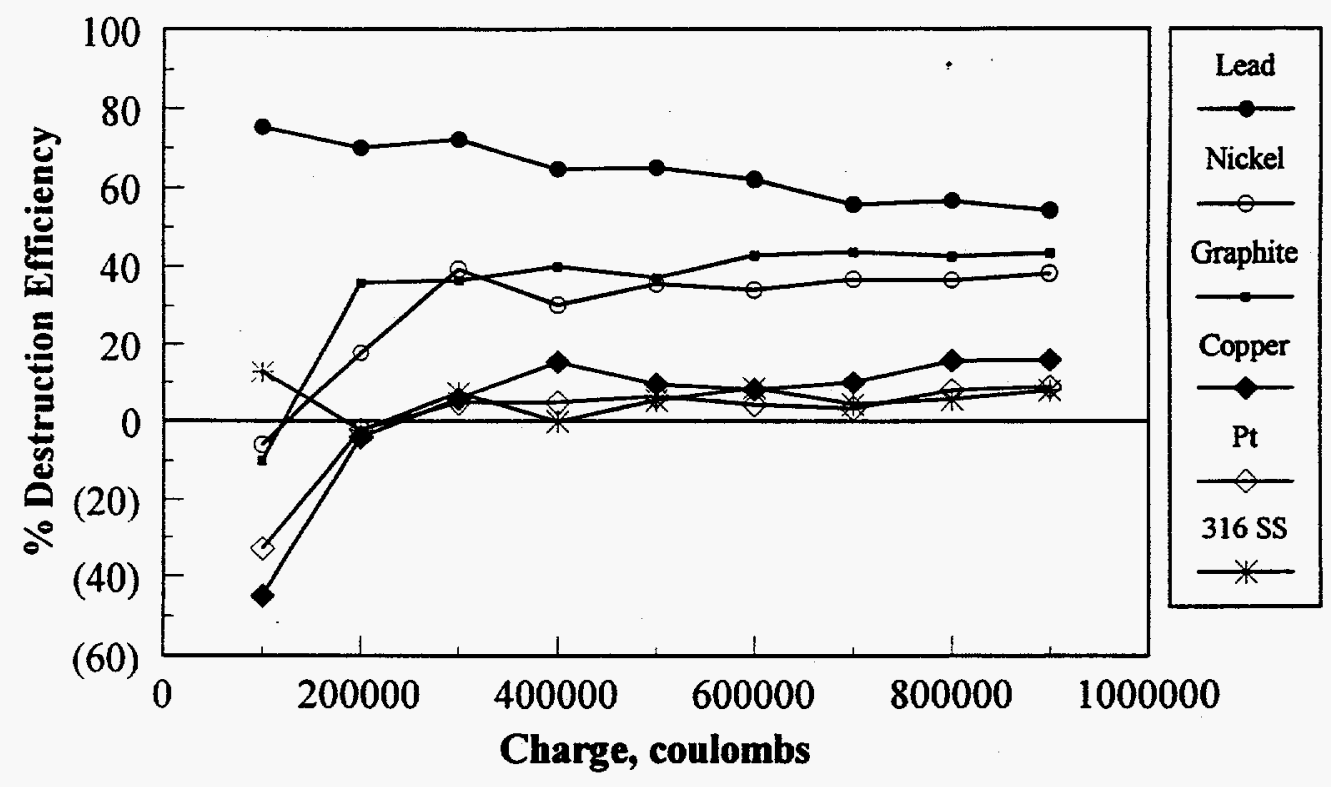

Solution analyses indicated that chromium was almost entirely removed form solution in the successful experiments with lead, nickel, and graphite cathodes but not removed when other cathodes were used. The literature indicates that chromate in base can form $\mathrm{Cr}(\mathrm{OH})_{3}$ films on platinum cathodes [21]. These films hinder the reduction of large molecules while still allowing hydrogen evolution to occur. Further chromate reduction is also hindered. The industrial process for chlorate electrosynthesis takes advantage of this behavior. Chromate is added to the electrolyte to prevent the reduction of intermediately formed hypochlorite ions to chloride at the cathode in the undivided cell. Perhaps at platinum, copper, and stainless steel, nitrate reduction, as well as chromate reduction, is hindered by the formation of chromium hydroxide films. At nickel, graphite, and lead, film formation is not fully supported, and reduction of nitrate and nitrite continued.

Since the reduction process seems to be sensitive to other species present in the full waste simulant two of the promising cathode materials, nickel and lead, were screened in longer experiments to ensure that their performance remained the same with larger amounts of the mix. Figure 17 shows cumulative destruction efficiencies for the 50 hour cathode tests. Poor destruction efficiencies and low amounts of nitrogen containing reduction products were seen at nickel through the bulk of the run. Thus nickel performed quite differently in the 50 hour test than in the initial short screening tests. The lead cathode gave cumulative destruction efficiencies similar to those seen in shorter experiments. 
Ammonia was again the dominant reduction product in the latter half of the experiment. Lead performed very well in these extended tests and is clearly the best cathode material tested for reduction of nitrate and nitrite in the complete simulant.

\section{Figure 17. Destruction Efficiencies in 50-Hour Cathode Screening Tests}

Test Conditions: MP flow cell equipped with $\mathrm{Nafion}^{\circledR}$ type 417 membrane, DSA-O 2 anode, $5000 \mathrm{~A} / \mathrm{m}^{2}$ current density, $70^{\circ} \mathrm{C}, 3 \mathrm{M}$ sulfuric acid anolyte, flowrate $=1.0 \mathrm{gpm}$

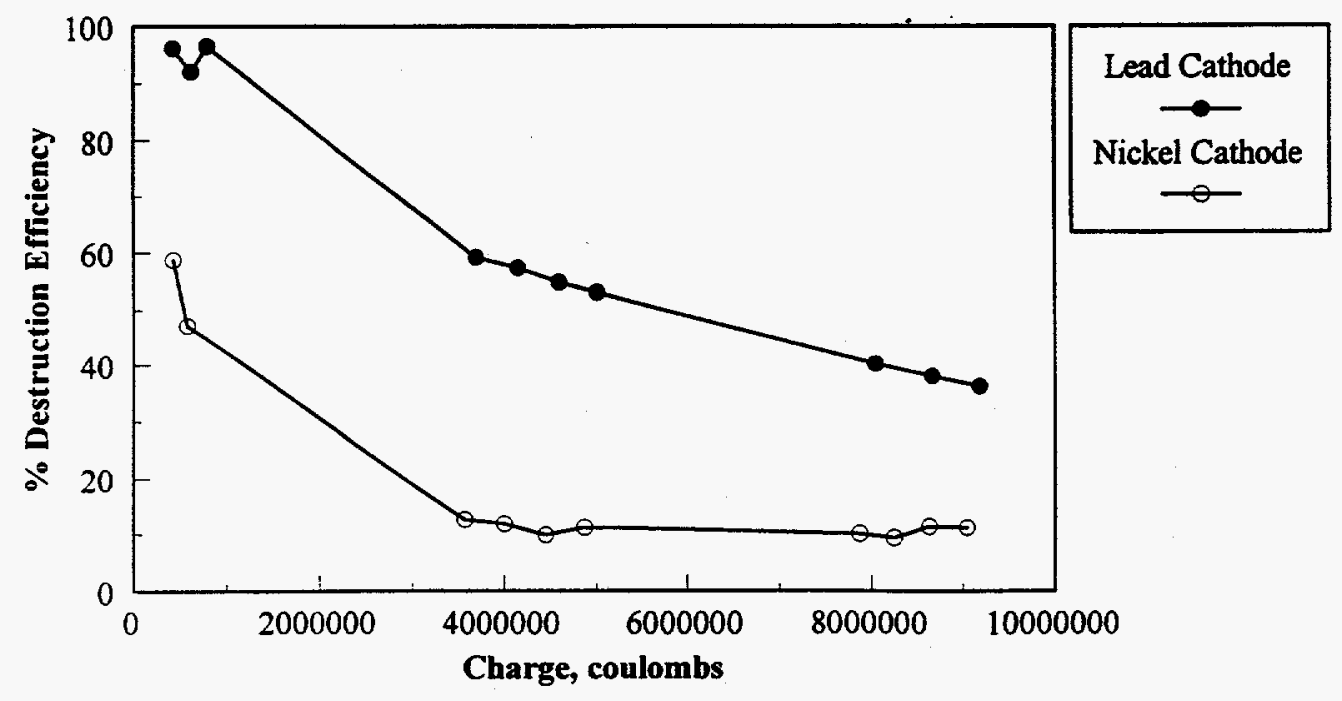

\subsection{Effect of Temperature and Current Density on Nitrate/Nitrite Reduction}

The combined effects of current density and temperature on the reduction of nitrate in the complete simulant were investigated in an undivided flow cell (FM01 LC, ICI) using a lead alloy (ICI $\mathrm{Pb} / \mathrm{Sn} / \mathrm{Ca}$ alloy) cathode and nickel anode. Figure 18 shows that destruction efficiencies were improved in experiments carried out at higher current densities. The higher current density does not impair the process and in fact provides greater $i R$ heating of the solution. The optimal conditions for nitrate/nitrite reduction in the flow cell with the complete simulant are high current density and high temperature. 
Figure 18. Effect of Current Density and Temperature on the Current Efficiency for Nitrate/Nitrite Destruction

Test Conditions: Undivided FMO1 flow cell equipped $\mathrm{Pb} / \mathrm{Sn} / \mathrm{Ca}$ alloy cathode and nickel anode, flowrate $=0.8 \mathrm{gpm}$, results reported at 1 million coulombs

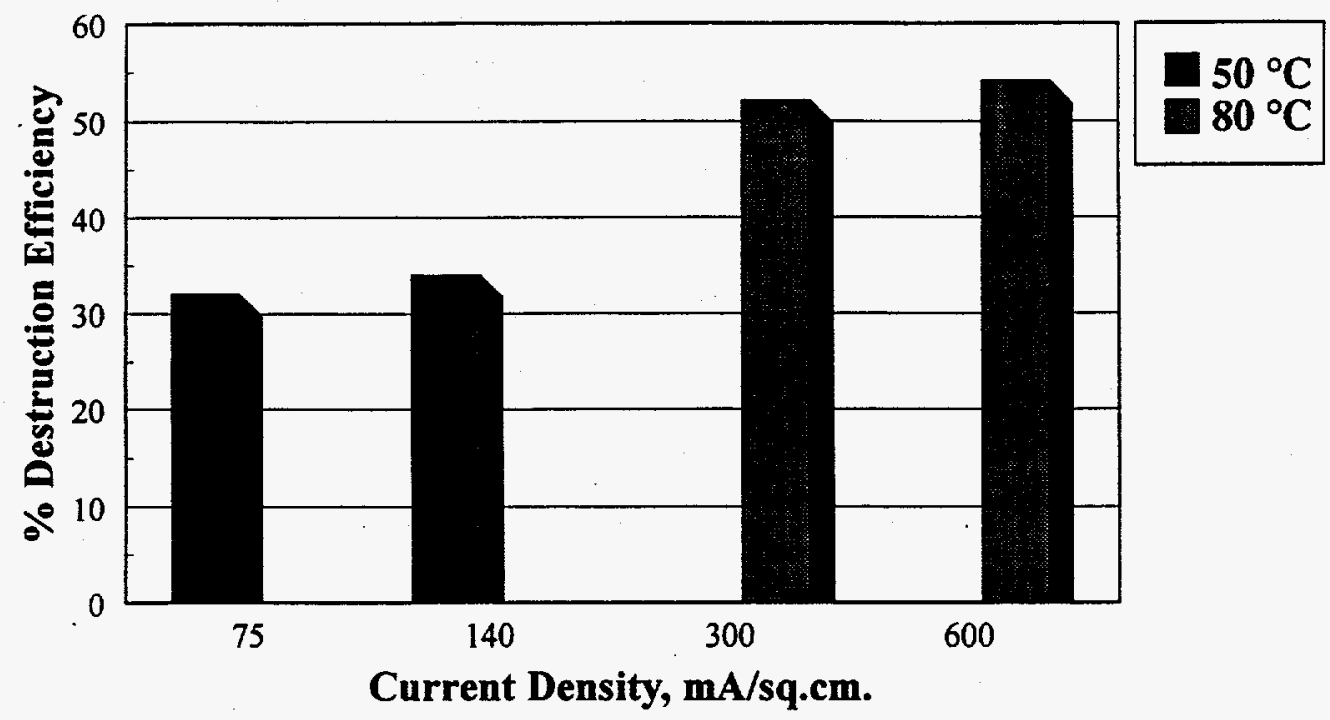

\subsection{Evaluation of Anode Materials}

Two requirements must be met by potential anode materials for nitrate reduction. First, the material would have to be stable to the complete solution matrix under actual electrolysis conditions. Second, the material should not interfere with the reduction process if the cell is operated in an undivided configuration.

\subsubsection{Undivided Flow Cell Anode Screening Tests}

Figure 19 summarizes the results of anode screening tests in an undivided MP flow cell with a lead cathode. In the undivided cell, the 316 stainless steel and nickel anodes showed slightly worse cumulative destruction efficiencies than those seen in the divided cell with a lead cathode. The stainless steel anode gave a large amount of rust colored solids in solution. No solids were seen in solution with the nickel anode but the anode was coated with precipitate and showed slight weight loss. The platinum anode did not show physical evidence of corrosion, but gave much poorer destruction efficiencies. Negative destruction efficiencies seen early in the experiment reflect a net oxidation of nitrite to nitrate. Two other anode materials tested in the undivided flow cell, graphite and lead, corroded severely. Thus, of the anode materials tested only nickel is suitable for the direct reduction of nitrate in an undivided cell. 
Figure 19. Comparison of Anode materials for Nitrate/Nitrite Reduction in an Undivided Flow Cell at a Lead Cathode

Test Conditions: Undivided MP flow cell with lead cathode, $5000 \mathrm{~A} / \mathrm{m}^{2}$ current density, $70^{\circ} \mathrm{C}$, flowrate $=1.0 \mathrm{gpm}$

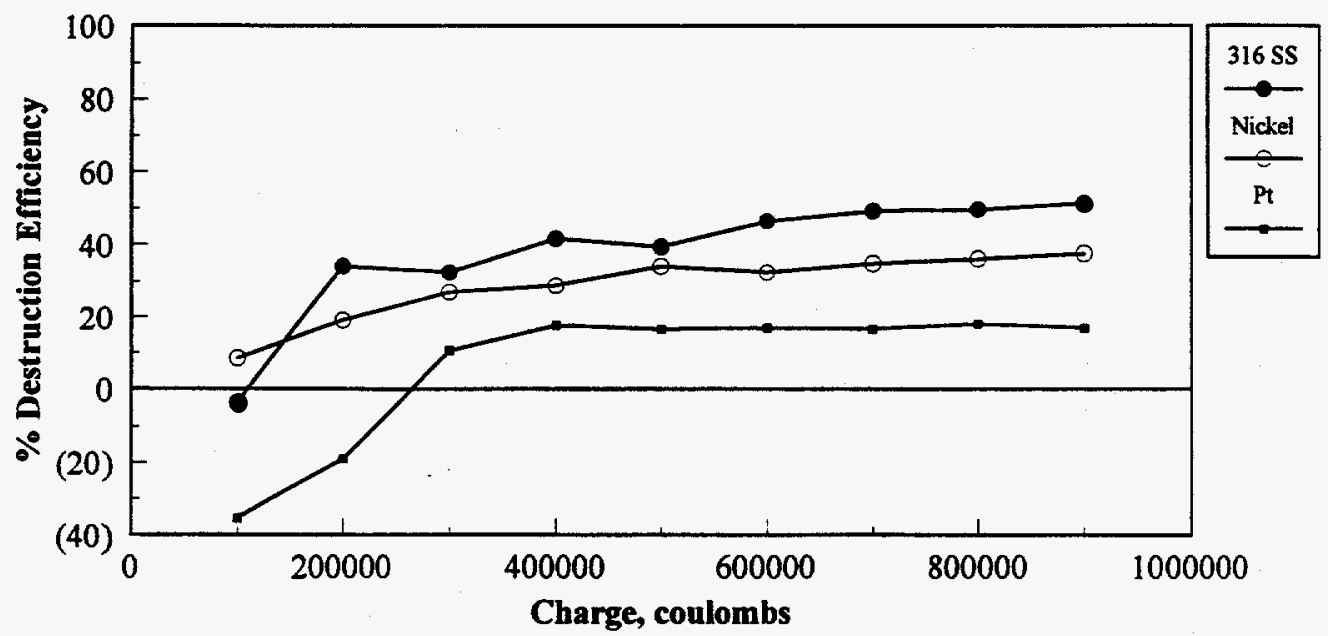

\subsection{Effect of Membrane on Nitrate Removal}

Figure 20 shows that the inclusion of a cation exchange membrane brings about a significant improvement for nitrate and nitrite reduction with a lead cathode and platinum anode. The membrane isolates the catholyte electrochemistry from interfering oxidation of nitrite at the anode. The figure shows that in the absence of a membrane, nitrite was removed but nitrate levels changed little, indicating that nitrite was oxidized to nitrate. As a result, cumulative destruction efficiencies for nitrate and nitrite removal are poor. When a membrane is included, both nitrite and nitrate are removed from solution at good destruction efficiencies. 
Test Conditions: MP flow cell equipped with lead cathode and $\mathrm{Pt}$ anode, $5000 \mathrm{~A} / \mathrm{m}^{2}$ current density, $70^{\circ} \mathrm{C}$, for divided cell configuration inserted Nafion ${ }^{\circledR}$ type 417 membrane between electrodes and used $3 \mathrm{M}$ sulfuric acid for the anolyte, flowrate $=1.0 \mathrm{gpm}$

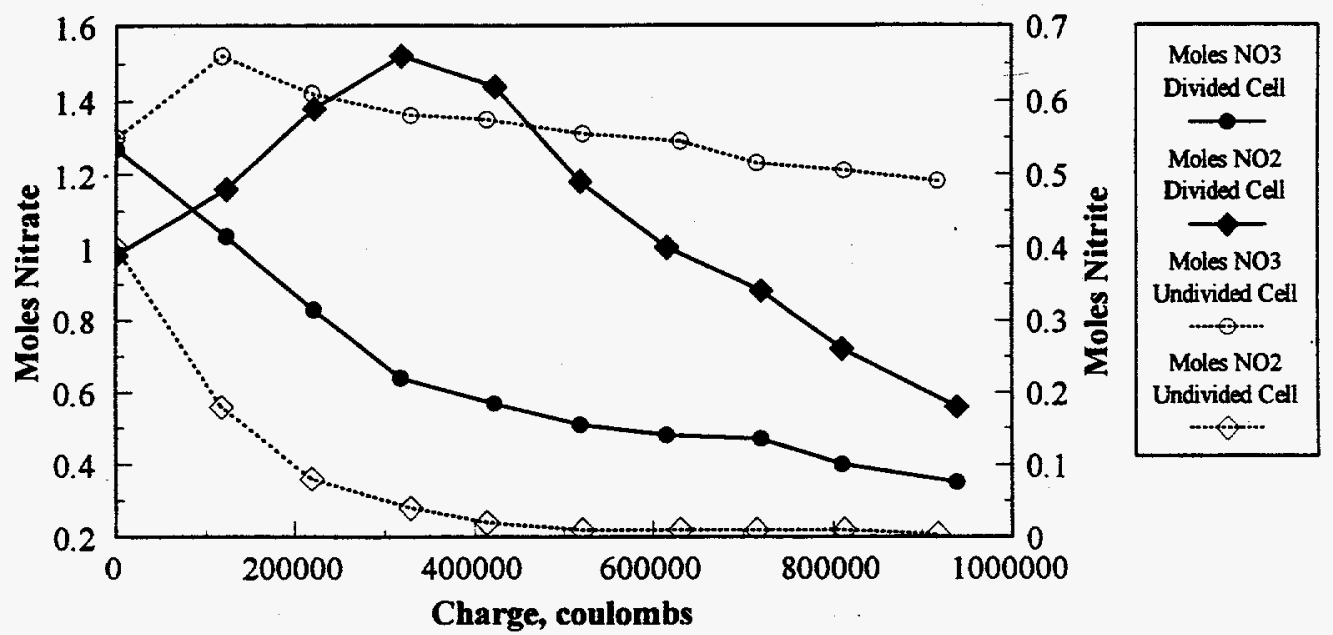

\begin{tabular}{|c|c|c|c|c|c|c|c|c|}
\hline Charge $\times 10^{5}$ (Coulombs) & 1.2 & $\underline{2,2}$ & 32 & 4.2 & 5.2 & 6.2 & 7.2 & $\underline{8.2}$ \\
\hline $\begin{array}{l}\text { \% Destruction Efficiency } \\
\text { Divided Cell }\end{array}$ & 75 & 65 & 62 & 56 & 57 & 54 & 54 & 57 \\
\hline \% Destruction Efficiency & -35 & -19 & 11 & 18 & 16 & 17 & 17 & 18 \\
\hline
\end{tabular}
Undivided Cell

\subsubsection{Effect of Radiation on Membranes}

For the direct reduction process to be feasible in a divided cell, the cation exchange membrane must not be damaged by radiation from trace amounts of radionuclides found in the waste stream. It is conceivable that radiation could cleave sulfonic acid groups off of the membrane's polymer backbone or even damage the fluorinated backbone of the membrane. Any such damage would presumably result in changes in membrane resistivity. Nafion ${ }^{\circledR}$ Type 324 and 417 membranes were exposed to a ${ }^{60}$ Co radiation source and irradiated at an accelerated dose rate $\left(4.7 \pm 0.6 \times 10^{4} \mathrm{rad} / \mathrm{hr}\right)$. One hour of irradiation at this dose rate was estimated to correspond to 6 months of exposure to the actual waste. The membranes were irradiated in three different solutions: deionized water, $0.1 \mathrm{M}$ sulfuric acid, and the complete synthetic mix to determine the effect, if any, of the sample matrix on possible radiation damage.

Figure 21 plots membrane potential vs. current density for unirradiated and irradiated membranes in the complete mix. The supporting electrolyte for the membrane potential tests was $2 \mathrm{M} \mathrm{H}_{2} \mathrm{SO}_{4}$. The membrane potential includes the solution iR drop between the Luggin probes and the membrane. Control experiments with unirradiated membranes gave a variation in membrane potential of about $15 \mathrm{mV}$ at $500 \mathrm{~mA} / \mathrm{cm}^{2}$. The graph shows no clear trend in terms of changes of resistivity with irradiation. Similar results were seen with those membranes irradiated in sulfuric acid and in water. 
An irradiated Nafion ${ }^{\circledR}$ Type 324 membrane was placed in a MP flow cell and the cell operated for 100 hours. The cell potential and the rate of nitrate and nitrite destruction were similar to that for a cell equipped with an unirradiated membrane. Thus, it was concluded that irradiation of the Nafion ${ }^{\circledR}$ membrane of up to a total dose of $3.8 \times 10^{5} \mathrm{rad}$ did not result in damage to the membrane that would affect its performance in the flow cell.

Figure 21. Effects of Irradiation on Membrane Potential

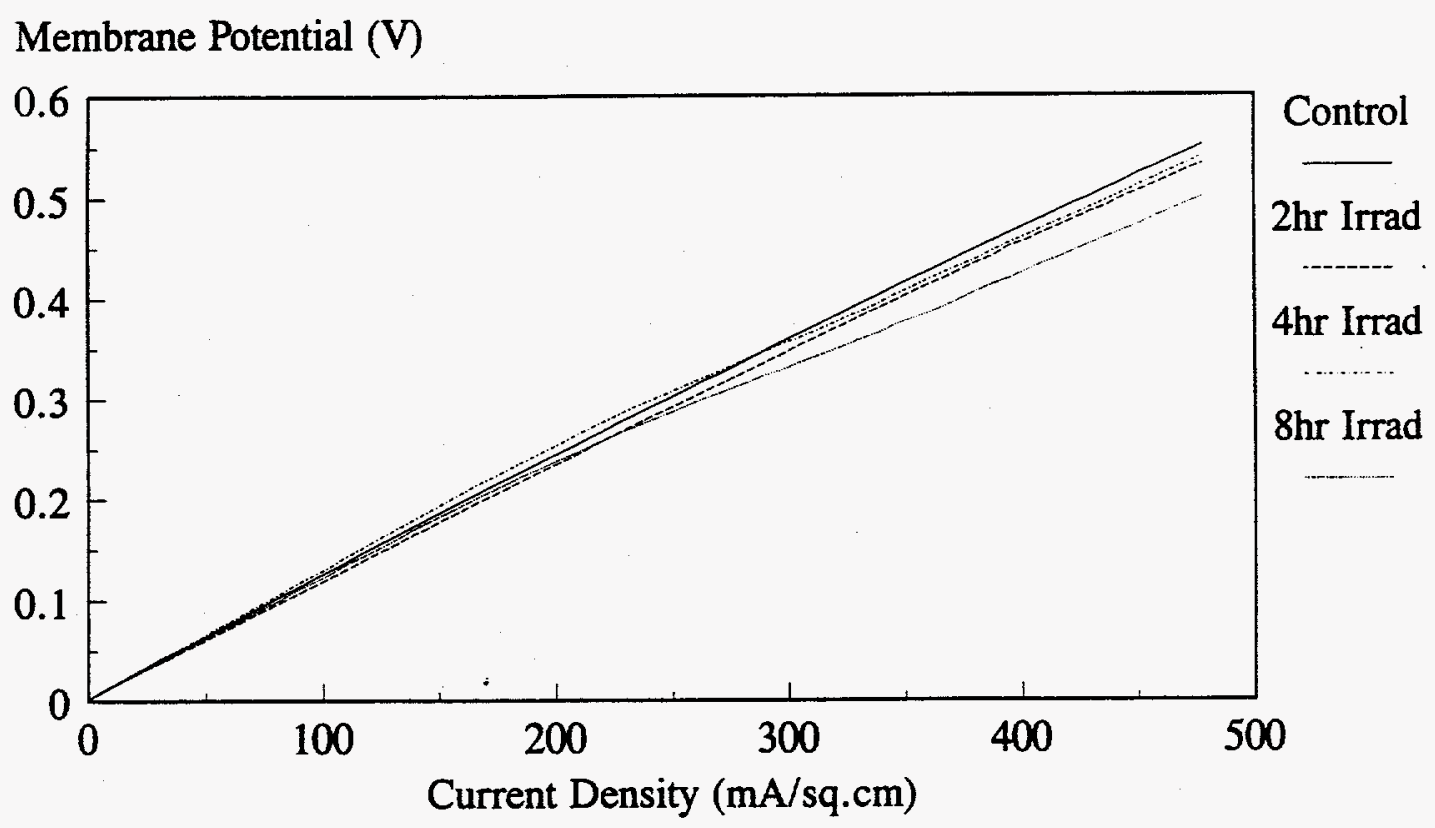

\subsection{Long Term Flow Cell Component Performance and Stability Tests}

From the previous short duration tests, the optimal conditions found for nitrate and nitrite reduction in the complete simulant included: high temperature, high current density, divided cell, and lead cathode. These conditions were examined in long-term performance and stability tests. A divided MP cell equipped with a lead cathode, a Nafion ${ }^{\circledR}$ Type 417 cation exchange membrane, and one of the following anodes: (1) oxygen evolving DSA, (2) platinized niobium, or (3) shiny platinum-clad niobium anode was evaluated at a current density of $5000 \mathrm{~A} / \mathrm{m}^{2}$ and a temperature of $70{ }^{\circ} \mathrm{C}$. A large batch of the complete simulant containing enough nitrate/nitrite to run for approximately 1000 hours was used as the catholyte.

\subsubsection{Long Term Testing With 3M Sulfuric Acid Anolyte}

The performance of the direct reduction at a lead cathode was similar in the long-term studies to that seen in shorter experiments. Overall a destruction efficiency of $55 \%$ was achieved and greater than $99 \%$ of the nitrite and nitrate was removed. Chromate was completely removed form solution early in the experiments. The lead cathode and Nafion ${ }^{\circledR}$ Type 417 membrane showed good stability and performance over the 1000 hour time frame. 
Each anode tested (oxygen evolving DSA type, platinized niobium, platinum clad niobium) failed after several hundred hours of operation due to corrosion. Anode failure was evidenced by rising cell voltage as the precious metal coating of these electrodes was etched exposing the passive titanium or niobium substrate. Solution analyses of the sulfuric acid anolytes all showed high levels of the precious metals used to coat the electrodes as well as the base metal. Scanning electron microscopy of the anodes also demonstrated that etching had occurred often to the extent of complete removal of large areas of the catalyst coating.

Solution analyses also showed high amounts of fluoride (>10 ppm) in the anolyte. Apparently, fluoride migrated across the cation exchange membrane from the catholyte into the anolyte under the influence of the potential field. Anions are known to diffuse across cation exchange membranes at rates that would readily give $10 \mathrm{ppm}$ fluoride in the anolyte[11]. In the acidic anolyte fluoride would form HF, a highly aggressive species known to attack oxygen evolving DSA-type anodes. Fluoride contamination of the acidic anolyte is likely responsible for the corrosion and failure of the anodes.

\subsubsection{Long Term Test with 10M Sodium Hydroxide Anolyte}

One means of avoiding anode corrosion in a divided cell would be to utilize a caustic anolyte. Fluoride migrating into this media would form NaF instead of $\mathrm{HF}$ and may not cause corrosion. Furthermore, the use of inexpensive anode materials such as stainless steel may be possible. The source of caustic could be the $\mathrm{NaOH}$ produced by the reduction of nitrate and nitrite and recovered from the spent catholyte by evaporation and crystallization.

This concept was tested in the MP flow cell using a lead cathode, Nafion ${ }^{\circledR}$ Type 324 membrane (previously irradiated in a Co radiation field to a total dose of $1.9 \times 10^{5}$ rad; see section 5.4.1), and a stainless steel anode operating at a current density of $5000 \mathrm{~A} / \mathrm{m}^{2}$ and a temperature of $70^{\circ} \mathrm{C}$. Destruction efficiencies were similar to those seen with an acid anolyte. The experiment continued smoothly for over 100 hours with no indication of corrosion.

\section{Tests with Other Simulated SRS Waste Streams}

In addition to the electrolytic destruction of nitrate and nitrite in concentrated salt solutions such as decontaminated salt solution, electrochemical treatment of several other SRS waste streams was also evaluated. A brief description of the waste stream, the treatment objective, and test results are provided below.

\subsection{Sludge Supernatant Liquid}

Tests were carried out to evaluate the destruction of nitrate in the supernatant liquid associated with the sludge fraction of HLW. The objective of this treatment was to reduce the corrosivity of the solution by reducing the nitrate concentration. By reducing the nitrate concentration, considerable savings in the amount of corrosion inhibitors that would be required to prevent corrosion during processing and storage of sludge slurries would be realized.

Evaluation of the nitrate destruction in sludge supernatant liquid was carried out in SRTC-2 electrochemical reactor equipped with a nickel cathode and anode. The composition of the sludge supernatant liquid is very similar to that of the decontaminated salt solution. The composition of the sludge supernatant liquid simulant used in these tests is shown in Table $\mathrm{X}$ below. 
Nitrate and nitrite were observed to be reduced during electrolysis of the simulated sludge supernatant liquid solution. Thus, the corrosivity of the solution was decreased by reducing the nitrate concentration and increasing the hydroxide concentration. A series of runs at different current densities was carried out to determine the rate of nitrate destruction. The destruction rate varied linearly with the current density.

\section{Table X. Composition of Sludge Supernatant Liquid Simulant}

$\begin{array}{ll}\text { Species } & \text { Concentration }(\mathrm{M}) \\ \mathrm{NaNO}_{3} & 2.5 \\ \mathrm{NaNO}_{2} & 0.14 \\ \mathrm{NaOH} & 0.95 \\ \mathrm{NaCl} & 0.0016 \\ \mathrm{Na}_{2} \mathrm{CO}_{3} & 0.084 \\ \mathrm{Na}_{2} \mathrm{SO}_{4} & 0.18\end{array}$

Nitrite is also a corrosion inhibitor used at SRS to prevent stress corrosion cracking and pitting corrosion during the storage and processing of $\mathrm{HLW}$ in carbon steel tanks. If the electrolysis reaction were limited to the conversion of nitrate to nitrite, much lower power costs could be achieved since only a two electron reaction versus a five to eight electron reaction is being carried out. Under constant current electrolysis, however, the ratio of nitrate to nitrite remained fairly constant, indicating that the nitrite was undergoing further reaction as it was produced. In principle, nitrite production would be possible under constant potential conditions.

\subsection{Seepage Basin Solution}

Since startup of F-Area and H-Area Separations facilities, dilute liquid wastes have been released to seepage basins in each of the areas. These basins were closed to new waste receipts in 1988 when the Effluent Treatment Facility began operation. Nitrate is calculated to pose the maximum environmental risk for the release of non-radioactive species from these basins. A single test was carried out to determine if the nitrate could be destroyed electrolytically so that the nitrate release risk would be reduced. In contrast to the previous solutions, the seepage basin solution is acidic.

For this test, the electrolytic cell consisted of a $500 \mathrm{~mL}$ platinum crucible that served as the anode, and a 1-inch nickel pipe that served as the cathode. The seepage basin simulant (see Table XI for composition) was added to the crucible and 0.1 amperes of current at a potential of 4.6 volts passed through the solution. After a total of $2.5 \mathrm{amp}-$ hours, over $50 \%$ of the nitrate had been destroyed with no detectable amount of nitrite. 
Table XI. Composition of Seepage Basin Simulant

$\begin{array}{ll}\text { Species } & \text { Concentration }(\mathrm{M}) \\ \mathrm{NO}_{3}{ }^{-} & 0.026 \\ \mathrm{CO}_{3}{ }^{2-} & 0.0030 \\ \mathrm{NO}_{2}{ }^{-} & 2.17 \times 10^{-4} \\ \mathrm{Cl}^{-} & 8.46 \times 10^{-4} \\ \mathrm{SO}_{4}{ }^{2-} & 3.12 \times 10^{-4} \\ \mathrm{~F}^{-} & 6.32 \times 10^{-4} \\ \mathrm{SiO}_{3}{ }^{2-} & 1.39 \times 10^{-3} \\ \mathrm{H}^{+} & 0.010 \\ \mathrm{NH}_{4}{ }^{+} & 1.66 \times 10^{-3} \\ \mathrm{Fe}^{3+} & 4.3 \times 10^{-4} \\ \mathrm{Na}^{+} & 0.0111\end{array}$

\subsection{DWPF Off-Gas Recycle Stream}

Condensates from the Defense Waste Processing Facility (DWPF) will be collected and returned to the Tank Farm. Nitrate is the major component in this waste stream. Prior to sending this stream to the Tank Farm, considerable amounts of sodium hydroxide will be added to this waste stream to inhibit against corrosion during storage in carbon steel tanks. Electrolytic destruction of the nitrate was investigated to reduce the corrosivity and inhibitor requirements of this waste stream.

The composition of the DWPF Off-Gas Recycle Stream simulant is provided in Table XII. Testing was carried out in the SRTC-2 reactor equipped with a nickel cathode and anode. At a pH of 9.5 , very little destruction of the nitrate was observed. At a $\mathrm{pH}$ of 10.5 , the rate of destruction was $0.0016 \mathrm{~mole} / \mathrm{L} / \mathrm{hr}$. At a pH of $13.0\left(0.1 \mathrm{M} \mathrm{OH}^{-}\right)$, the rate increased to $0.0027 \mathrm{~mole} / \mathrm{L} / \mathrm{hr}$, and at a $\mathrm{pH}$ of $13.4\left(0.25 \mathrm{M} \mathrm{OH}^{-}\right)$, the rate was measured to be $0.026 \mathrm{~mole} / \mathrm{L} / \mathrm{hr}$. Because of the high alkalinity needed to affect reduction of the nitrate, there would be minimal savings in the amounts of corrosion inhibitor consumed, and therefore, the application of electrolytic treatment was not further explored. 
Table XII. DWPF Off-Gas Recycle Stream Simulant Composition

Species

$\mathrm{NaNO}_{3}$

$\mathrm{Na}_{2} \mathrm{C}_{2} \mathrm{O}_{4}$

$\mathrm{NaOCHO}$

$\mathrm{NaOC}_{6} \mathrm{H}_{5}$

$\mathrm{HgCl}_{2}$

$\mathrm{Na}_{2} \mathrm{SO}_{4}$

$\mathrm{NaCl}$

$\mathrm{NaF}$

$\mathrm{NaI}$

$\mathrm{H}_{2} \mathrm{O}$
Concentration (wt \%)

0.40

0.26

0.084

0.0336

0.0215

0.0176

0.0202

0.0055

0.0008

99.16

$\mathrm{pH}$ of solution adjusted with $\mathrm{NaOH}$ to 9.5

\subsection{Washed ITP Precipitate Slurry}

The washed ITP precipitate slurry is treated in the DWPF with formic acid in the presence of a copper catalyst to hydrolyze the tetraphenylborate resulting in the release of benzene. The benzene is steam distilled from the aqueous fraction, condensed, and stored for later incineration. The removal of benzene is necessary to reduce the organic carbon feed to the melter.

Nitrite that is present in the slurry during the hydrolysis step has been found to react with the aromatic compounds producing high-boiling compounds that are difficult to steam distill. The high-boiling organic compounds remain with the aqueous phase and are sent to the melter cell. Electrolytic treatment of the washed precipitate slurry was investigated to remove the nitrite and thus reduce the formation of high-boiling organic compounds. Tests were carried out with a simulated slurry having the composition shown in Table XIII. 
Table XIII. Composition of Washed Precipitate Slurry Simulant

$\begin{array}{ll}\text { Species } & \text { Concentration }(\mathrm{M}) \\ \mathrm{NO}_{3}{ }^{-} & 0.084 \\ \mathrm{NO}_{2}{ }^{-} & 0.27 \\ \mathrm{OH}- & 0.030 \\ \mathrm{~B}\left(\mathrm{C}_{6} \mathrm{H}_{5}\right)_{4}{ }^{-} & 0.27 \\ \mathrm{Cl}^{-} & 0.0012 \\ \mathrm{CO}_{3}{ }^{2-} & 0.0071 \\ \mathrm{SO}_{4}{ }^{2-} & 0.0060 \\ \mathrm{C}_{2} \mathrm{O}_{4}{ }^{2-} & 0.0088 \\ \mathrm{CrO}_{4}{ }^{2-} & 2.7 \times 10^{-4} \\ \mathrm{Na}^{+} & 0.29 \\ \mathrm{~K}^{+} & 0.47 \\ \mathrm{NH}_{4}{ }^{+} & 0.0023 \\ \mathrm{Cs}^{+} & 0.0021 \\ \mathrm{Ti}^{4+} & 0.017\end{array}$

Tests were carried out in the SRTC-2 electrochemical cell equipped with a nickel cathode and anode. In the undivided cell, nitrite was observed to be quickly oxidized to nitrate. Upon further electrolysis, the nitrate was destroyed. Concurrently with the removal of nitrite and nitrate, foaming and darkening of slurry was observed. The darkening was due to reactions of the organic compounds resulting in the formation of highly-colored products such as those produced during acid hydrolysis. Several tests were carried out at constant potential in an attempt to selectively oxidize nitrite only. However, in all of the electrolyses, the organic slurry darkened indicating reaction of the organic compounds. Since selective oxidation was not observed for this waste stream, no additional development work in this application was conducted. It is possible however, that continue oxidation of the organic compounds would result in the complete conversion of the organic compounds to carbon dioxide and water.

\section{CONCLUSIONS}

Electrochemical destruction of nitrate and nitrite has been demonstrated in laboratoryscale cells under a variety of operating conditions and waste compositions including actual SRS waste. Nitrogen, ammonia, and nitrous oxide have been identified as the nitrogen-containing reaction products. The reaction mechanism for the reduction of nitrate and nitrite is very complex. Voltammetric studies have indicated that the electrode reactions involve surface phenomena and are not necessarily mass transfer controlled. In an undivided cell, results suggest an electrocatalytic role for oxygen via the generation of the superoxide anion.

In general, more efficient reduction of nitrite and nitrate occurs at those cathode materials with higher overpotentials for hydrogen evolution. Nitrate and nitrite destruction has also been demonstrated in engineering-scale flow reactors. In flow reactors, the nitrate/nitrite destruction efficiency was improved with an increase in the 
current density, temperature, and operation of the cell in a divided configuration. Nafion ${ }^{\circledR}$ cation exchange membranes have exhibited good stability and consistent performance as separators in divided-cell tests. The membranes were also shown to be unaffected by radiation at doses approximating four years of cell operation with ITP decontaminated salt solution.

Electrochemical removal of technetium and ruthenium in actual and simulated SRS wastes has also been demonstrated. Both are deposited on the cathode. The amount deposited depends on the cathode surface characteristics and solution composition. Technetium can be removed from the cathode by reversing the cell polarity and reoxidizing the technetium to pertechnetate. Removal of the deposited ruthenium required physical means.

Tests indicate that the Coll (cyclam) complex is an effective catalyst in strong base, approximately to the same extent as in neutral or nonaqueous solutions. Nearly complete reduction of nitrate and nitrite to mixtures of hydroxylamine and ammonia takes place with reasonable current efficiencies at a variety of electrode materials. Complexation of nitrate (or nitrite) by a $\mathrm{Co}^{\mathrm{I}}$ species and adsorption of the $\mathrm{Co}^{\mathrm{I}}$ intermediate is suggested from the experimental studies. A role for the electrode material is indicated by dependence of the catalytic current on the CoI(cyclam) complex concentration, which differs for the various electrodes employed.

\section{ACKNOWLEDGEMENTS}

This work was funded by the Office of Technology Development, Office of Environmental Management through the Efficient Separations and Processing Integrated Program, Teresa B. Fryberger, Headquarters Program Manager, and James A. Wright, cognizant Technical Program Officer.

The work summarized in this report was the result of the efforts of a number of individuals including: A. Mindler at the International Hydronics Corporation, J. Q. Chambers, H.-L. Li, D. H. Robertson, W. C. Anderson, and C. Tsintavis at the University of Tennessee, J. D. Genders, D. Hartsough, N. Weinberg, and J. Colman at the Electrosynthesis Company, Inc., and M. Blume and I. Kelly at the Savannah River Technology Center.

\section{REFERENCES}

1. B. Bosnich, C. K. Poon, and M. L. Tobe, Inorg. Chem., 1965, 4, 1102.

2. F. Dias, A. S. Ologola, and B. Jaselskis, Talanta, 1979, 26, 47.

3. E. W. Baumann, Volumetric Determination of Hydroxide, Aluminate, and Carbonate in Alkaline Solutions of Nuclear Waste," DP-1386, June, 1975.

4. D. Wohrle, R. Bannehr, B. Schumann, G. Meyer, and N. Jaeger, J. Mol. Catalysis. 1983, 21, 255.

5. H. W. Alter, D. L. Barney, J. K Davidson, A. C. Schafer, Jr., "Electrolytic Recycle Method for the Treatment of Radioactive Nitric Acid Waste," DAPL-1721, June 26, 1957.

6. A. F. Messing and I. R. Higgins, "An Electrolytic Procedure for the Removal of Ruthenium and Nitrate from Alkaline Waste Solutions," ORNL-2532, September 19, 1958. 
7. A. B. Mindler and S. B. Tuwiner, "Electrolytic Reduction of Nitrate from Solutions of Alkali Metal Hydroxide," U.S. Patent 3,542,657, November 24, 1970.

8. A. B. Mindler, "Final Report - Feasibility Study - Electrochemical Treatment of SDSS Waste," June 28, 1985.

9. A. B. Mindler, "Final Report - Electrolytic Denitrification of Decontaminated Salt Solution Bench Scale Tests," February 21, 1986.

10. A. B. Mindler, "Electrolyic Reduction of Nitrate from Solutions of Alkali Metal Hydroxides Contaminated by Oxidizing Transition Metal Ions," U.S. Patent, 4,632,737, December 30, 1986.

11. H.-L. Li, D. H. Robertson, J. Q. Chambers, and D. T. Hobbs, "Electrochemical Reduction of Nitrate and Nitrite in Concentrated Sodium Hydroxide at Platinum and Nickel Electrodes," Journal Electrochemical Society, 135, 1154-58 (1988).

12. H.-L. Li, J. Q. Chambers, and D. T. Hobbs, "Electroreduction of Nitrate Ions in Concentrated Sodium Hydroxide Solutions at Lead, Zinc, Nickel, and Phthalocyanine-Modified Electrodes," Journal Applied Electrochemistry, 18, 454-458 (1988).

13. H.-L. Li, J. Q. Chambers, and D. T. Hobbs, "Electrocatalytic Reduction of Nitrate and Nitrite at Nafion ${ }^{\circledR}$-coated Electrodes in Concentrated Sodium Hydroxide Solution," J. Electroanalytical Chemistry, 256(1988), 447-453.

14. H.-L. Li, W. C. Anderson, J. Q. Chambers, and D. T. Hobbs, "Electrocatalytic Reduction of Nitrate in Sodium Hydroxide Solution in the Presence of Low-Valent Cobalt-Cyclam Species," Inorganic Chemistry, 1989, 28, 863.

15. C. Tsintavis, H.-L. Li, J. Q. Chambers, and D. T. Hobbs, "Isomerization and Conformational Equilibria Coupled to Electron Transfer in a Macrocyclic Cobalt (III/T)-cyclam System in Sodium Hydroxide Solution," Inorganica Chimica Acta, 171 (1990), 1-3.

16. C. Tsintavis, H.-L. Li, J. Q. Chambers, and D. T. Hobbs, "Electrochemistry of cis- and trans1,4,8,11-Tetraazacyclo- tetradecane Complexes of Cobalt(III) at Gold Electrodes in Hydroxide Solution," Journal of Physical Chemistry, 1991, 95, 289-297.

17. W. R. Murphy, Jr., K. Takeuchi, M. H. Barley, and T. J. Meyer, Inorg. Chem., 1986, 25, 1041.

18. I. Taniguchi, N. Nakashima, K. Matsushita, K. Yasukouchi, J. Electroanal. Chem. Interfacial Electrochem., 1987, 224, 199.

19. D. T. Hobbs, "Electrolytic Denitrification of Decontaminated Salt Solution," DPST-86-226, January $11,1986$.

20. D. T. Hobbs, M. A. Ebra, and A. B. Mindler, "Electrolytic Denitrification of Alkaline Nitrate and Nitrite Solutions," Proceedings of the Symposium on Waste Management at Tucson, Arizona, March 1986, Volume 1, pages 643-646.

21. D. T. Hobbs and M. A. Ebra, "Electrochemical Processing of Alkaline Nitrate and Nitrite Solutions," AIChE Symposium Series No. 254 -- Electrochemical Engineering Applications, Volume 83,1987 , page $149-155$. 
22. D. T. Hobbs and M. A. Ebra, "Electrochemical Processing of Low-Level Waste Solutions," Proceedings of the Symposium on Waste Management at Tucson, Arizona, March 1987, Volume 3, pages 161-166.

23. D. T. Hobbs, "Electrochemical Treatment of Nuclear Waste at the Savannah River Site," Chapter 12 in Electrochemistry For A Cleaner Environment, edited by J. D. Genders and N. L. Weinberg, Electrosynthesis Company, Inc., East Amherst, New York, 1992.

24. J. D. Genders, "Final Report - Electrochemical Processing Of Nitrate Waste Solutions (U)," May 31, 1990 (WSRC-TR-90-491).

25. J. D. Genders, "Phase II Final Report - Electrochemical Processing Of Nitrate Waste Solutions, (U)" October 7, 1992 (WSRC-TR-93-090).

26. G. Lindbergh and D. Simmonsson, Electrochim. Acta., 1991, 36, 1985. 
Distribution:

T. B. Fryberger, DOE-HQ

J. A. Wright, DOE-SR, 703-A

M. G. Schwenker, DOE-SR, 704-H

W. L. Kuhn, PNL

J. E. Surma, PNL

M. Buehler, PNL

P. A. Taylor, ORNL

$\mathrm{K}$. Wendt, WINCO

R. E. White, University of South Carolina

J. W. Van Zee, University of South Carolina

J. O.'M. Bockris, Texas A\&M

J. D. Genders, Electrosynthesis Company

J. Q. Chambers, University of Tennessee

A. B. Minler, International Hydronics Corporation

W. L. Tamosaitis, 773-A

S. D. Fink, 773-A

R. F. Swingle, 773-A

D. J. McCabe, 773-A

IWT-LWP File, 773-A

TIM, 773-52A 